University of Nebraska - Lincoln

DigitalCommons@University of Nebraska - Lincoln

\title{
The mineralogic transformation of ferrihydrite induced by heterogeneous reaction with bioreduced anthraquinone disulfonate (AQDS) and the role of phosphate
}

John M. Zachara

Pacific Northwest National Laboratory, john.zachara@pnl.gov

Ravi K. Kukkadapu

Pacific Northwest National Laboratory, ravi.kukkadapu@pnl.gov

Tanya Peretyazhko

Pacific Northwest National Laboratory

Mark Bowden

Pacific Northwest National Laboratory

Chongmin Wang

Pacific Northwest National Laboratory

See next page for additional authors

Follow this and additional works at: https://digitalcommons.unl.edu/usdoepub

Part of the Bioresource and Agricultural Engineering Commons

Zachara, John M.; Kukkadapu, Ravi K.; Peretyazhko, Tanya; Bowden, Mark; Wang, Chongmin; Kennedy, David; Moore, Dean; and Arey, Bruce, "The mineralogic transformation of ferrihydrite induced by heterogeneous reaction with bioreduced anthraquinone disulfonate (AQDS) and the role of phosphate" (2011). US Department of Energy Publications. 263.

https://digitalcommons.unl.edu/usdoepub/263

This Article is brought to you for free and open access by the U.S. Department of Energy at DigitalCommons@University of Nebraska - Lincoln. It has been accepted for inclusion in US Department of Energy Publications by an authorized administrator of DigitalCommons@University of Nebraska - Lincoln. 


\section{Authors}

John M. Zachara, Ravi K. Kukkadapu, Tanya Peretyazhko, Mark Bowden, Chongmin Wang, David Kennedy, Dean Moore, and Bruce Arey 


\title{
The mineralogic transformation of ferrihydrite induced by heterogeneous reaction with bioreduced anthraquinone disulfonate (AQDS) and the role of phosphate
}

\author{
John M. Zachara*, Ravi K. Kukkadapu, Tanya Peretyazhko, Mark Bowden, \\ Chongmin Wang, Dave W. Kennedy, Dean Moore, Bruce Arey
}

Pacific Northwest National Laboratory, P.O. Box 999, MSIN K8-96, Richland, WA 99354, USA

Received 4 November 2010; accepted in revised form 27 April 2011; available online 29 June 2011

\begin{abstract}
Bioreduced anthraquinone-2,6-disulfonate $\left(\mathrm{AH}_{2} \mathrm{DS}\right.$; dihydro-anthraquinone) was reacted with a 2-line, Si-substituted ferrihydrite under anoxic conditions at neutral $\mathrm{pH}$ in PIPES buffer. Phosphate $(\mathrm{P})$ and bicarbonate $(\mathrm{C})$; common adsorptive oxyanions and media/buffer components known to effect ferrihydrite mineralization; and $\mathrm{Fe}(\mathrm{II})_{\mathrm{aq}}$ (as a catalytic mineralization agent) were used in comparative experiments. Heterogeneous $\mathrm{AH}_{2} \mathrm{DS}$ oxidation coupled with Fe(III) reduction occurred within 0.13-1 day, with mineralogic transformation occurring thereafter. The product suite included lepidocrocite, goethite, and/or magnetite, with proportions varing with reductant:oxidant ratio (r:o) and the presence of $\mathrm{P}$ or $\mathrm{C}$. Lepidocrocite was the primary product at low r:o in the absence of $\mathrm{P}$ or $\mathrm{C}$, with evidence for multiple formation pathways. Phosphate inhibited reductive recrystallization, while $\mathrm{C}$ promoted goethite formation. Stoichiometric magnetite was the sole product at higher r:o in the absence and presence of $\mathrm{P}$. Lepidocrocite was the primary mineralization product in the Fe(II) $)_{\mathrm{aq}}$ system, with magnetite observed at near equal amounts when $\mathrm{Fe}(\mathrm{II})$ was high $[\mathrm{Fe}(\mathrm{II}) / \mathrm{Fe}(\mathrm{III})]=0.5$ and $\mathrm{P}$ was absent. $\mathrm{P}$ had a greater effect on reductive mineralization in the $\mathrm{Fe}(\mathrm{II})_{\mathrm{aq}}$ system, while AQDS was more effective than $\mathrm{Fe}(\mathrm{II})_{\mathrm{aq}}$ in promoting magnetite formation. The mineral products of the direct $\mathrm{AH}_{2} \mathrm{DS}$-driven reductive reaction are different from those observed in $\mathrm{AH}_{2} \mathrm{DS}$-ferrihydite systems with metal reducing bacteria, particularly in presence of $\mathrm{P}$.
\end{abstract}

(C) 2011 Elsevier Ltd. All rights reserved.

\section{INTRODUCTION}

Dissimilatory $\mathrm{Fe}(\mathrm{III})$ reduction under anoxic geochemical conditions is an important biogeochemical process in soils, sediments, and subsurface systems mediated by metal reducing bacteria (MRB). The process has been extensively studied (Geomicrobiology, 2002; DiChristina et al., 2005; Kappler and Straub, 2005; Roden, 2006; Weber et al., 2006). Dissimilatory Fe(III) reduction influences system redox state and buffering capacity (Fredrickson et al., 2004;

\footnotetext{
* Corresponding author. Tel.: +1 509371 6355; fax: +1 509371 6354.

E-mail address: john.zachara@pnl.gov (J.M. Zachara).
}

Komlos et al., 2007); the valence and composition of pore-water solutes (Baedecker et al., 1993; Bennett et al., 1993); the identity, surface properties, and geochemical reactivity of the Fe-containing mineral fraction (e.g., Zachara et al., 2004; Plymale et al., 2011); and the chemical form, persistence, and fate of a wide range of inorganic and organic contaminants (Lovley and Anderson, 2000).

MRB access $\mathrm{Fe}(\mathrm{III})$ in mineral forms by direct cellular contact (Nevin and Lovley, 2000a; Mehta et al., 2005; Shi et al., 2007), dissolution-promoting Fe(III) chelators (Taillefert et al., 2007; Jones et al., 2010), and water soluble endogenous or exogenous electron transfer mediators (ETM; Nevin and Lovley, 2000b; Straub and Schink, 2003; Marsili et al., 2008; O’Loughlin, 2008). The dissimilatory reduction of numerous $\mathrm{Fe}(\mathrm{III})$-containing subsurface

0016-7037/\$ - see front matter (c) 2011 Elsevier Ltd. All rights reserved. doi:10.1016/j.gca.2011.06.030 
mineral forms have been studied, with recognition that high surface area and high solubility are conducive to bioreduction because of surface chemical and thermodynamic constraints (Roden and Zachara, 1996; Bonneville et al., 2004; Roden, 2006; Yan et al., 2008). The following bioavailability sequence has been observed based on total $\mathrm{Fe}($ III) mass: ferrihydrite $\sim$ lepidocrocite $>$ nanocrystalline $\mathrm{Fe}(\mathrm{III})$ oxides $>\mathrm{Fe}(\mathrm{III})$ containing phyllosilicates (smectite, nontronite, illite) $>$ crystalline $\mathrm{Fe}$ (III) oxides (Roden and Zachara, 1996; Kostka et al., 2002; Zachara et al., 2002; Bonneville et al., 2004). The bioreduction of ferrihydrite and lepidocrocite, specifically, can lead to major changes in mineralogy (Fredrickson et al., 1998; Hansel et al., 2003; Kukkadapu et al., 2004, 2005; O’Loughlin et al., 2007).

The addition of the synthetic ETM, 9,10-anthraquinone2,6-disulfonate (AQDS), to an anoxic MRB-Fe(III) mineral suspension with a suitable electron donor greatly enhances the $\mathrm{Fe}(\mathrm{III})$ reduction rate and extent (Fredrickson et al., 1998; Zachara et al., 1998; Royer et al., 2002; Dong et al., 2003; Hernandez et al., 2004; Chacon et al., 2006; Kukkadapu et al., 2006; Behrends and van Cappellen, 2007; Jaisi et al., 2007; Coker et al., 2008; Cutting et al., 2009). AQDS is a widely used model ETM for environmental and contaminant redox transformations of diverse type (Curtis and Reinhard, 1994; Borch et al., 2005; Bhushan et al., 2006; Kwon and Finneran, 2006, 2008; Zhang et al., 2007). AQDS is a synthetic three-ring quinone with structural analogy to quinone groups in humic substances (Curtis and Reinhard, 1994), and to biogenic quinones (Nurmi and Tratnyek, 2002). AQDS has a relatively low half-cell potential, and rapid redox kinetics (Nurmi and Tratnyek, 2002). It readily engages with the electron transport system of certain MRB (Shyu et al., 2002; Voordeckers et al., 2010), being reduced to the dihydroanthraquinone state $\left(\mathrm{AH}_{2} \mathrm{DS}\right)$ :

$\mathrm{AQDS}+2 \mathrm{H}^{+}+2 \mathrm{e}^{-}=\mathrm{H}_{2} \mathrm{DS} \quad \mathrm{E}^{\mathrm{o}}=0.23 \mathrm{~V}$

The $\mathrm{AH}_{2} \mathrm{DS}$ form is poorly adsorbed, but rapidly reactive with $\mathrm{Fe}(\mathrm{III})$ oxides (Liu et al., 2007a). The product of the heterogeneous $\mathrm{AH}_{2} \mathrm{DS}$ reaction with $\mathrm{Fe}(\mathrm{III})$ mineral phases is $\mathrm{Fe}(\mathrm{II})$ in either a structural or adsorbed state that has not been well characterized.

Numerous studies of ferrihydrite or lepidocrocite reductive biomineralization by MRB have used AQDS as a mediator, observing that its presence yields more crystalline mineralogic products (e.g., Fredrickson et al., 1998; Zachara et al., 1998). Reductive mineral phases have been observed in AQDS-containing Fe(III) oxide systems, such as green rust and ferrous hydroxy carbonate (Ona-Nguema et al., 2002; Kukkadapu et al., 2004, 2005; O'Loughlin et al., 2007; O'Loughlin, 2008), that are infrequently observed in its absence. These mineral forms are considered biomineralization products, but are they? Unclear is whether noted mineralogic differences between AQDS $( \pm)$-ferrihydrite/lepidocrocite-MRB systems result from the heterogeneous reaction pathways of $\mathrm{AH}_{2} \mathrm{DS}$; unique biogenic kinetic flux rates of $\mathrm{AH}_{2} \mathrm{DS}, \mathrm{Fe}(\mathrm{II})$, or $\mathrm{HCO}_{3}{ }^{-}$ (resulting from electron donor oxidation); or changes in bacteria-mineral biophysical interaction, aggregation, and the consequent interfacial microenvironment. Some believe that AQDS has no direct influence or control on the nature of bioreductive mineral products other than a kinetic one (Zegeye et al., 2007; Coker et al., 2008).

As a first step in understanding the AQDS-ferrihydrite/ lepidocrocite-MRB system, we investigated mineral transformations promoted by interaction of bioreduced AQDS with a Si-containing, 2-line ferrihydrite. We varied the $\mathrm{AH}_{2} \mathrm{DS} / \mathrm{Fe}(\mathrm{III})$ ratio and investigated the effects of phosphate $\left(\mathrm{PO}_{4}^{3-}\right)$ and bicarbonate $\left(\mathrm{HCO}_{3}{ }^{-}\right)$, ubiquitous natural ligands and common components of bacterial incubation media, on reductive mineral transformation. Resultant mineral products were characterized by scanning and transmission electron microscopy, X-ray diffraction, and variable temperature Mössbauer spectroscopy. The mineralization promoting effects of $\mathrm{AH}_{2} \mathrm{DS}$ were compared to those of $\mathrm{Fe}(\mathrm{II})_{(\mathrm{aq})}$, and the results of Hansel et al. (2005) and Borch et al. (2007), who studied similar Fe(II) systems.

\section{MATERIALS AND METHODS}

\subsection{Two-line 0.02 Si-ferrihydrite}

Two-line ferrihydrite containing $2 \% \mathrm{Si}[\mathrm{Si} /(\mathrm{Si}+\mathrm{Fe})$ mole fraction $=0.02]$ was prepared using ferric nitrate $\left(0.333 \mathrm{~mol} \mathrm{~L}^{-1}\right)$ and sodium meta-silicate $\left(0.012 \mathrm{~mol} \mathrm{~L}^{-1}\right)$ solutions (Kukkadapu et al., 2004). Silica was co-precipitated with ferrihydrite to retard the progress of oxidative recrystallization reactions (e.g., to 6-line ferrihydrite, goethite, and hematite) that proceed relatively rapidly in its absence (Anderson and Benjamin, 1985; Kukkadapu et al., 2003; Dyer et al., 2010). The resulting ferrihydrite suspension was washed with $1.0 \times 10^{-4} \mathrm{~mol} \mathrm{~L}^{-1} \mathrm{NaClO}_{4}$ to remove nitrate and dissolved $\mathrm{Si}$, and (1) stored as $\sim 5.0 \times$ $10^{-1} \mathrm{~mol} \mathrm{~L}^{-1} \mathrm{Fe}$ suspension (pH 7.0) in $1.0 \times 10^{-4} \mathrm{~mol} \mathrm{~L}^{-1}$ $\mathrm{NaClO}_{4}$ at $4{ }^{\circ} \mathrm{C}$ [for $\mathrm{AH}_{2} \mathrm{DS}$ experiments (Section 3.1)], or (2) manipulated to yield $1.0 \times 10^{-2} \mathrm{~mol} \mathrm{~L}^{-1}$ ferrihydrite in $1.0 \times 10^{-2} \mathrm{~mol} \mathrm{~L}^{-1}$ anoxic PIPES buffer at $\mathrm{pH} 7$ [for Fe(II) experiments (Section 3.2)]. The Si-ferrihydrite was recrystallization stable for months in suspensions that are saturated with atmospheric oxygen.

\subsection{Bioreduced AQDS ( $\left.\mathrm{AH}_{2} \mathrm{DS}\right)$}

AQDS was incubated with Shewanella oneidensis strain MR-1 in presence of $\mathrm{H}_{2}$ (electron donor) to yield $\mathrm{AH}_{2} \mathrm{DS}$ (Liu et al., 2007a). The method involved incubation at $30{ }^{\circ} \mathrm{C}$ and $150 \mathrm{rpm}$ of $160 \mathrm{~mL}$ serum bottles containing $90 \mathrm{~mL}$ of AQDS, $30 \mathrm{~mL} \mathrm{H}$, and $10 \mathrm{~mL}$ washed cells in $3.0 \times 10^{-2} \mathrm{~mol} \mathrm{~L}^{-1}$ anaerobic buffer [PIPES (head space $\mathrm{O}_{2}$-free $\mathrm{N}_{2}$ )]. This composition corresponded to $2 \times$ $10^{8}$ cells $\mathrm{mL}^{-1}$ and $5.0 \times 10^{-3} \mathrm{~mol} \mathrm{~L}^{-1}$ AQDS. The bottles were incubated until a color change (4-6 d) indicated conversion of AQDS to $\mathrm{AH}_{2} \mathrm{DS}$. Complete reduction of AQDS to $\mathrm{AH}_{2} \mathrm{DS}$ was confirmed by UV-VIS spectroscopy (Liu et al., 2007a). The $\mathrm{AH}_{2} \mathrm{DS}$ solution was anaerobically filtered $(0.2 \mu \mathrm{m})$ into a sterile serum vial to remove cell fragments, and tightly sealed. 
Bacterial reduction of AQDS to $\mathrm{AH}_{2} \mathrm{DS}$ was selected because it was representative of the MRB-AQDS system that we sought to understand. Additionally, it was more effective than abiotic synthesis, yielding $>98 \% \mathrm{AH}_{2} \mathrm{DS}$ solutions. It is possible that other redox-active biomolecules may have been secreted to solution during $\mathrm{AH}_{2} \mathrm{DS}$ synthesis, although these are likely to be low in concentration in the absence of a carbon source. Potential candidates include riboflavin and riboflavin 5 '-phosphate, compounds suspected to be electron transfer mediators (Marsili et al., 2008). Direct analyses of $S$. oneidensis MR-1 cultures, the organism used here for AQDS reduction, place FMN and riboflavin at nominal concentrations of 250-500 nM (Marsili et al., 2008), or $<0.01 \%$ of the total $\mathrm{AH}_{2} \mathrm{DS}$ concentration. Reductive dissolution experiments performed in our laboratory with these compounds and 2-line ferrihydrite indicate that these low flavin concentrations did not influence the outcome of the experiments reported herein because of the large excess of $\mathrm{AH}_{2} \mathrm{DS}$.

\subsection{Reductive transformation of 2-line Si-ferrihydrite with $\mathrm{AH}_{2} \mathrm{DS}$}

$\mathrm{AH}_{2} \mathrm{DS}$ concentrations were chosen to yield two $\mathrm{Fe}(\mathrm{II})_{\mathrm{e}}$ quiv $/ \mathrm{Fe}(\mathrm{III})$ ratios $\left(0.11,0.54\right.$; where $\mathrm{Fe}(\mathrm{II})_{\text {equiv }} / \mathrm{Fe}(\mathrm{III})=$ $2\left[\mathrm{AH}_{2} \mathrm{DS}\right] /\left(\mathrm{Fe}(\mathrm{III})_{\text {initial }}-2\left[\mathrm{AH}_{2} \mathrm{DS}\right]\right)$ after its heterogeneous oxidation by ferrihydrite (Table 1$)$. The lower ratio is slightly below the threshold value $(0.124)$ reported by Hansel et al. (2005) for magnetite formation, while the higher value (0.54) is approximately equal to the $\mathrm{Fe}(\mathrm{II}) /$ $\mathrm{Fe}(\mathrm{III})$ ratio in magnetite $(0.5)$. Ferrihydrite in $3.0 \times$ $10^{-2}$ mol L ${ }^{-1}$ PIPES buffer $\left(100 \mathrm{~mL} ; \mathrm{pH} 7 ; \mathrm{O}_{2}\right.$-free $\mathrm{N}_{2}$ head space), untreated or pretreated (overnight) with $\mathrm{PO}_{4}^{3-}(\mathrm{P})$ and/or $\mathrm{HCO}_{3}{ }^{-}(\mathrm{C})$, was incubated with the two $\mathrm{AH}_{2} \mathrm{DS}$ concentrations for $0.13,1$, and $30 \mathrm{~d}$. These incubation times were chosen based on a scoping experiment that identified the time period of transformation. The $\mathrm{AH}_{2} \mathrm{DS}, \mathrm{P}$, and $\mathrm{C}$ concentrations; and $\mathrm{AH}_{2} \mathrm{DS} / \mathrm{Fe}, \mathrm{Fe}(\mathrm{II})_{\text {equiv }} / \mathrm{Fe}(\mathrm{III})$, $\mathrm{P} /(\mathrm{Fe}+\mathrm{P})$, and $\mathrm{C} /(\mathrm{Fe}+\mathrm{C})$ ratios of the experiments are summarized in Table 1. The incubations were carried out in $160 \mathrm{~mL}$ serum bottles with butyl rubber stoppers and Al crimp-seals at $30^{\circ} \mathrm{C}$ and $25 \mathrm{rpm}$ horizontal shaking. The $\mathrm{C}$ concentrations $\left(0.25\right.$ and $0.75 \times 10^{-3} \mathrm{~mol} \mathrm{~L}^{-1}$ as $\mathrm{HCO}_{3}{ }^{-}$) are typical of groundwater, and those found as an electron donor oxidation product in MRB-Fe(III) oxide suspensions (Fredrickson et al., 1998). The P concentration $\left(0.6 \times 10^{-3} \mathrm{~mol} \mathrm{~L}^{-1}\right)$ falls at the low end of that used in MRB laboratory studies.

\subsection{Treatment of 2-line Si-ferrihydrite with aqueous $\mathrm{Fe}(\mathrm{II})$}

Aqueous ferrous iron concentrations of $0.5,3.3$, and $5.0 \times 10^{-3} \mathrm{~mol} \mathrm{~L}^{-1}$ were selected to bracket the $\mathrm{Fe}(\mathrm{II})_{\mathrm{e}}$ quiv $/ \mathrm{Fe}(\mathrm{III})$ ratio of 0.11 used in the $\mathrm{AH}_{2} \mathrm{DS}$ experiment at the low end, and to approximate the ratio of 0.54 at the high end. Approximately $17.5 \mathrm{~mL}$ of 2-line Si-ferrihydrite $\left(2.0 \times 10^{-2} \mathrm{~mol} \mathrm{~L}^{-1}\right)$ in $1.0 \times 10^{-3} \mathrm{~mol} \mathrm{~L}^{-1}$ PIPES buffer ( $\mathrm{pH} 7 ; \mathrm{O}_{2}$-free $\mathrm{N}_{2}$ head space), untreated or pretreated overnight with $2 \% \mathrm{P}$, was contacted with the three concentrations of $\mathrm{Fe}\left(\mathrm{ClO}_{4}\right)_{2}$ (in $17.5 \mathrm{~mL}$ of $1.0 \times$
$10^{-2} \mathrm{~mol} \mathrm{~L}^{-1}$ PIPES buffer, $\mathrm{pH} 7$ ) for $0.13,1,30$, and $63 \mathrm{~d}$. The experiments were performed in $160 \mathrm{~mL}$ serum bottles with butyl rubber stoppers and $\mathrm{Al}$ crimp-seals at $30{ }^{\circ} \mathrm{C}$ and $25 \mathrm{rpm}$ horizontal shaking. Unlike the $\mathrm{AH}_{2} \mathrm{DS}$ experiments, bicarbonate additions were not made to these experiments to avoid siderite precipitation.

\subsection{Analyses}

After equilibration, the ferrihydrite suspensions were sampled in an anaerobic $\left(\mathrm{N}_{2}: \mathrm{H}_{2}, 95: 5\right)$ glove bag (Coy Laboratory Products Inc., Grass Lake, MI). Approximately, $0.4 \mathrm{~mL}$ of suspension filtrate $(0.2 \mu \mathrm{m}$; after discarding first 20 drops) was combined with $0.4 \mathrm{~mL}$ of $1 \mathrm{~mol} \mathrm{~L}^{-1} \mathrm{HCl}$ in an eppendorf tube, for aqueous $\mathrm{Fe}(\mathrm{II})$ measurements. Acid-extractable $\mathrm{Fe}(\mathrm{II})$ was obtained by placing a $0.4 \mathrm{~mL}$ aliquot of the suspension into $0.4 \mathrm{~mL}$ of $1 \mathrm{~mol} \mathrm{~L}^{-1} \mathrm{HCl}$ or $10 \mathrm{~mol} \mathrm{~L}^{-1} \mathrm{HCl}$ and equilibrating for $24 \mathrm{~h}$. The higher acid concentration was used when crystalline phases, goethite and magnetite primarily, were the transformation products. The $\mathrm{HCl}$ extracts and aqueous fractions were analyzed for $\mathrm{Fe}(\mathrm{II})$ by the ferrozine assay (Stookey, 1970). $\mathrm{Fe}_{\text {total }}$ and $\mathrm{P}$ concentrations were determined on select samples using inductively coupled plasma emission spectroscopy (ICP). Suspension filtrates from the $\mathrm{AH}_{2} \mathrm{DS}$ experiments $(<0.2 \mu \mathrm{m})$ were diluted in anoxic water, sealed in cuvettes, removed from the glove bag, and scanned from 500 to $300 \mathrm{~nm}$ with a Shimadzu UV/VIS spectrophotometer to measure the absorbance of AQDS at $325 \mathrm{~nm}$ and of $\mathrm{AH}_{2} \mathrm{DS}$ at $386 \mathrm{~nm}$ (Liu et al., 2007a).

\subsection{1. ${ }^{57} \mathrm{Fe}$-Mössbauer spectroscopy, X-ray diffraction, and electron microscopy}

Mössbauer samples were created by filtering $(0.45 \mu \mathrm{m})$ $\sim 5 \mathrm{~mL}$ of the mineral suspension under anoxic conditions. The resulting filter membrane containing the moist mineral residue was placed into a $\mathrm{Cu}$ sample holder that was filled with petroleum jelly and sealed at both ends with scotch tape (another sub-sample of the suspension was dried in the anaerobic chamber for XRD and microscopy). An $\mathrm{O}_{2}$ impermeable polymer (aluminized Mylar) was used as a seal at each end of the holder. Both the tape and polymer were snapped into the holder with rings made of PEEK polymer. The Mössbauer disks were stored in the anoxic chamber until analysis.

Mössbauer spectra were collected using a $50 \mathrm{mCi}$ (initial strength) ${ }^{57} \mathrm{Co} / \mathrm{Rh}$ source. The velocity transducer MVT1000 (WissEL) was operated in a constant acceleration mode $(23 \mathrm{~Hz}, \pm 12 \mathrm{~mm} / \mathrm{s})$. An Ar-Kr proportional counter analyzed transmitted radiation, and the counts were stored in a multichannel scalar (MCS) as a function of energy (transducer velocity) using a 1024 channel analyzer. Data were folded to 512 channels to give a flat background and a zero-velocity position corresponding to the center shift (CS) of a metal iron foil at room temperature (RT). Calibration spectra were obtained with a $25 \mu \mathrm{m}$ thick $\alpha-\mathrm{Fe}(\mathrm{m})$ foil (Amersham, England) placed in the same position as the samples to minimize sample geometry errors. A closed-cycle cryostat (ARS, Allentown, PA) was employed for low temperature measurements. The Mössbauer data 
Table 1

Chemical composition of various treatments.

\begin{tabular}{|c|c|c|c|c|c|c|c|c|c|c|c|}
\hline Treatment & Description & $\begin{array}{l}\mathrm{Fe}(\mathrm{III}) \text { in } \\
\text { 2-line } \mathrm{Si} \\
\text { Ferrihydrite } \\
\times 10^{-3} \mathrm{~mol} \mathrm{~L}^{-1}\end{array}$ & $\begin{array}{l}\mathrm{Fe}(\mathrm{II})_{\mathrm{aq}} \\
\times 10^{-3} \mathrm{~mol} \mathrm{~L}^{-1}\end{array}$ & $\begin{array}{l}\mathrm{AH}_{2} \mathrm{DS} \\
\times 10^{-3} \mathrm{~mol} \mathrm{~L}^{-1}\end{array}$ & $\begin{array}{l}\mathrm{Fe}(\mathrm{II})_{\text {equiv }}{ }^{\mathrm{b}} \\
\times 10^{-3} \mathrm{~mol} \mathrm{~L}^{-1}\end{array}$ & $\begin{array}{l}\mathrm{Fe}(\mathrm{II})_{\text {equiv }} / \\
\mathrm{Fe}(\mathrm{III})^{\mathrm{c}}\end{array}$ & $\begin{array}{l}\mathrm{NaH}_{2} \mathrm{PO}_{4} \\
\times 10^{-3} \mathrm{~mol} \mathrm{~L}^{-1}\end{array}$ & $\begin{array}{l}\mathrm{NaHCO}_{3} \\
\times 10^{-3} \mathrm{~mol} \mathrm{~L}^{-1}\end{array}$ & $\begin{array}{l}\mathrm{AH}_{2} \mathrm{DS} / \\
\mathrm{Fe}\end{array}$ & $\begin{array}{l}\mathrm{P} /(\mathrm{Fe}+\mathrm{P}) \\
\text { or }(\% \mathrm{P})^{\mathrm{a}}\end{array}$ & $\begin{array}{l}\mathrm{C} /(\mathrm{Fe}+\mathrm{C}) \\
\text { or }(\% \mathrm{C})^{\mathrm{a}}\end{array}$ \\
\hline 1 & $\mathrm{AH}_{2} \mathrm{DS},-\mathrm{P},-\mathrm{C}$ (PIPES) & 31.4 & - & 1.5 & 3.0 & 0.11 & - & - & 0.05 & - & - \\
\hline 2 & $\mathrm{AH}_{2} \mathrm{DS},-\mathrm{P},+\mathrm{C}$ (PIPES) & 31.4 & - & 1.5 & 3.0 & 0.11 & - & 0.25 & 0.05 & - & $0.008(0.8 \%)$ \\
\hline 3 & $\mathrm{AH}_{2} \mathrm{DS},-\mathrm{P},+\mathrm{C}(\mathrm{PIPES})$ & 31.4 & - & 1.5 & 3.0 & 0.11 & - & 0.75 & 0.05 & - & $0.024(2.4 \%)$ \\
\hline 4 & $\mathrm{AH}_{2} \mathrm{DS},+\mathrm{P},-\mathrm{C}(\mathrm{PIPES})$ & 31.4 & - & 1.5 & 3.0 & 0.11 & 0.6 & - & 0.05 & $0.02(2 \%)$ & - \\
\hline 5 & $\mathrm{AH}_{2} \mathrm{DS},+\mathrm{P},+\mathrm{C}(\mathrm{PIPES})$ & 31.4 & - & 1.5 & 3.0 & 0.11 & 0.6 & 0.75 & 0.05 & $0.02(2 \%)$ & $0.024(2.4 \%)$ \\
\hline 6 & $\mathrm{AH}_{2} \mathrm{DS},-\mathrm{P},-\mathrm{C}$ (PIPES) & 23.5 & - & 3.75 & 7.5 & 0.54 & - & - & 0.175 & - & - \\
\hline 7 & $\mathrm{AH}_{2} \mathrm{DS},+\mathrm{P},-\mathrm{C}(\mathrm{PIPES})$ & 23.5 & - & 3.75 & 7.5 & 0.54 & 0.3 & - & 0.175 & $0.02(2 \%)$ & - \\
\hline 8 & $\mathrm{Fe}(\mathrm{II})_{\mathrm{aq}},-\mathrm{P}(\mathrm{PIPES})$ & 10 & 1.0 & - & 0.5 & 0.05 & - & - & - & - & - \\
\hline 9 & $\mathrm{Fe}(\mathrm{II})_{\mathrm{aq}},+\mathrm{P}(\mathrm{PIPES})$ & 10 & 1.0 & - & 0.5 & 0.05 & 0.2 & - & - & $0.02(2 \%)$ & - \\
\hline 10 & $\mathrm{Fe}(\mathrm{II})_{\mathrm{aq}},-\mathrm{P}(\mathrm{PIPES})$ & 10 & 3.3 & - & 3.3 & 0.33 & - & - & - & - & - \\
\hline 11 & $\mathrm{Fe}(\mathrm{II})_{\mathrm{aq}},+\mathrm{P}(\mathrm{PIPES})$ & 10 & 3.3 & - & 3.3 & 0.33 & 0.2 & - & - & $0.02(2 \%)$ & - \\
\hline 12 & $\mathrm{Fe}(\mathrm{II})_{\mathrm{aq}},-\mathrm{P}(\mathrm{PIPES})$ & 10 & 5.0 & - & 5 & 0.50 & - & - & - & - & - \\
\hline 13 & $\mathrm{Fe}(\mathrm{II})_{\mathrm{aq}},+\mathrm{P}(\mathrm{PIPES})$ & 10 & 5.0 & - & 5 & 0.50 & 0.2 & - & - & $0.02(2 \%)$ & - \\
\hline
\end{tabular}

Mole fractions are shown as $\% \mathrm{P}$ and $\% \mathrm{C}$ in parentheses.

The concentration of $\mathrm{Fe}(\mathrm{II})$ resulting from $\mathrm{AH}_{2} \mathrm{DS}$ oxidation or direct $\mathrm{Fe}(\mathrm{II})$ addition.

c Assumes $100 \%$ oxidation for $\mathrm{AH}_{2} \mathrm{DS}$ experiments: $\mathrm{Fe}(\mathrm{II})_{\mathrm{equiv}} / \mathrm{Fe}(\mathrm{III})=2\left[\mathrm{AH}_{2} \mathrm{DS}\right] /\left(\mathrm{Fe}(\mathrm{III})_{\text {initial }}-2\left[\mathrm{AH}_{2} \mathrm{DS}\right]\right)$. For $\mathrm{Fe}(\mathrm{III})_{\mathrm{aq}}$ experiments: $\mathrm{Fe}(\mathrm{II})_{\mathrm{equiv}}=\mathrm{Fe}(\mathrm{II})_{\text {aq }} / \mathrm{Fe}(\mathrm{III})_{\text {initial }}$ where $\mathrm{Fe}(\mathrm{III})_{\text {ini }}$ tial $=\mathrm{Fe}(\mathrm{III})$ in 2-line Si ferrihydrite. Note that $\mathrm{Fe}(\mathrm{II}) / \mathrm{Fe}(\mathrm{III})=0.5$ for stoichiometric magnetite. Values of $0.67,1.0$, and $6.7 \mathrm{mmol} \mathrm{Fe}(\mathrm{II}) / \mathrm{g}$ of ferrihydrite reported by Hansel et al. (2005), represent $\mathrm{Fe}(\mathrm{II})_{\text {equiv }} / \mathrm{Fe}(\mathrm{III})$ ratios of $0.083,0.12$, and 0.83 , respectively. The value of $1.0 \mathrm{mmol} \mathrm{Fe}(\mathrm{II}) / \mathrm{g}$ of ferrihydrite or $\mathrm{Fe}(\mathrm{II})_{\text {equiv }} / \mathrm{Fe}(\mathrm{III})=0.124$ is reported by $\mathrm{Hansel}$ et al. (2005) as a threshold value for magnetite formation. 
were modeled with the Recoil software (University of Ottawa, Canada) using a Voigt-based structural fitting routine (Rancourt and Ping, 1991). The coefficient of variation of the spectral areas of the individual sites generally ranged between $1 \%$ and $2 \%$ of the fitted values.

Powder XRD patterns for mineral residues 1-7 (Table 1) were obtained with a Philips PW3040/00 X'pert MPD system, using $\mathrm{CuK}_{\alpha}$ radiation with a variable divergent slit and a solid-state detector. The routine power was $700 \mathrm{~W}(35 \mathrm{kV}$, $20 \mathrm{~mA}$ ). Mineral suspensions were filtered through a $0.2 \mu \mathrm{m}$ nylon filter and dried under anoxic conditions. The powder samples were packed into wells (1/4 inch diameter and 1/ 32 inch deep) of low-background quartz XRD slides. Packing was carried out in the anoxic chamber, but XRD measurements were performed in ambient atmosphere. An earlier study (Kukkadapu et al., 2004) showed little oxidation of the dried powders during XRD analysis.

In order to alleviate concerns over oxidation during $\mathrm{XRD}$ analyses, mineral residues from the $\mathrm{Fe}(\mathrm{II})_{\mathrm{aq}}$ experiments (\#8-13, Table 1) were analyzed as a moist paste in sealed micro-capillaries $(0.5 \mathrm{~mm})$. The capillaries were filled in an anoxic glovebox $\left(\mathrm{O}_{2}<0.5 \mathrm{ppm}\right)$. A Rigaku D/MAX-

Table 2

Mineral products of ferrihydrite reaction with $\mathrm{AH}_{2} \mathrm{DS}$ and $\mathrm{Fe}(\mathrm{II})_{\mathrm{aq}}$.

\begin{tabular}{|c|c|c|c|c|c|c|}
\hline \multirow[t]{2}{*}{ Treatment } & \multirow[t]{2}{*}{ Description } & \multirow[t]{2}{*}{$\mathrm{Fe}(\mathrm{II})_{\text {equiv }} / \mathrm{Fe}(\mathrm{III})$} & \multirow[t]{2}{*}{ Final $\mathrm{pH}$} & \multicolumn{3}{|l|}{ Mineralogy } \\
\hline & & & & $0.13 \mathrm{~d}$ & $1 \mathrm{~d}$ & $30 \mathrm{~d}$ \\
\hline 1 & $\mathrm{AH}_{2} \mathrm{DS},-\mathrm{P},-\mathrm{C}(\mathrm{PIPES})$ & 0.11 & 7.3 & $2 \mathrm{LF}$ & $2 \mathrm{LF}$ & $\mathrm{L} \gg>\mathrm{G}$ \\
\hline 2 & $\mathrm{AH}_{2} \mathrm{DS},-\mathrm{P},+\mathrm{C}(\mathrm{PIPES})$ & 0.11 & 7.0 & & $\mathrm{~L}>>\mathrm{G}$ & $\mathrm{L}>>\mathrm{G}$ \\
\hline 3 & $\mathrm{AH}_{2} \mathrm{DS},-\mathrm{P},+\mathrm{C}(\mathrm{PIPES})$ & 0.11 & 8.0 & $2 \mathrm{LF}>>\mathrm{G}^{*}$ & $G^{*}$ & $\mathrm{G}$ \\
\hline 4 & $\mathrm{AH}_{2} \mathrm{DS},+\mathrm{P},-\mathrm{C}(\mathrm{PIPES})$ & 0.11 & 7.4 & $2 \mathrm{LF}$ & $2 \mathrm{LF} / 6 \mathrm{LF}$ & $2 \mathrm{LF} / 6 \mathrm{LF}$ \\
\hline 5 & $\mathrm{AH}_{2} \mathrm{DS},+\mathrm{P},+\mathrm{C}(\mathrm{PIPES})$ & 0.11 & 8.0 & $2 \mathrm{LF}$ & $2 \mathrm{LF} / 6 \mathrm{LF}$ & $2 \mathrm{LF} / 6 \mathrm{LF}$ \\
\hline 6 & $\mathrm{AH}_{2} \mathrm{DS},-\mathrm{P},-\mathrm{C}$ (PIPES) & 0.54 & 7.5 & $2 \mathrm{LF}$ & $2 \mathrm{LF} / \mathrm{M}^{*}$ & M \\
\hline 7 & $\mathrm{AH}_{2} \mathrm{DS},+\mathrm{P},-\mathrm{C}(\mathrm{PIPES})$ & 0.54 & 7.6 & $2 \mathrm{LF}$ & $2 \mathrm{LF} / \mathrm{M}^{*}$ & M \\
\hline 8 & $\mathrm{Fe}(\mathrm{II})_{\mathrm{aq}},-\mathrm{P}(\mathrm{PIPES})$ & 0.05 & 6.8 & $\mathrm{~L}$ & $\mathrm{~L}$ & $\mathrm{~L}$ \\
\hline 9 & $\mathrm{Fe}(\mathrm{II})_{\mathrm{aq}},+\mathrm{P}(\mathrm{PIPES})$ & 0.05 & 6.8 & $\mathrm{~F} \gg>>\mathrm{L}$ & $\mathrm{F}>\mathrm{L}$ & $\mathrm{L}$ \\
\hline 10 & $\mathrm{Fe}(\mathrm{II})_{\mathrm{aq}},-\mathrm{P}$ (PIPES) & 0.33 & 6.7 & $\mathrm{~L}$ & $\mathrm{~L}$ & $\mathrm{~L}>\mathrm{M}$ \\
\hline 11 & $\mathrm{Fe}(\mathrm{II})_{\mathrm{aq}},+\mathrm{P}(\mathrm{PIPES})$ & 0.33 & 6.7 & $\mathrm{~F}>>\mathrm{L}$ & $\mathrm{F}>\mathrm{L}$ & $\mathrm{L}$ \\
\hline 12 & $\mathrm{Fe}(\mathrm{II})_{\mathrm{aq}},-\mathrm{P}(\mathrm{PIPES})$ & 0.50 & 6.5 & $\mathrm{~L}$ & $\mathrm{~L}$ & $\mathrm{~L} \approx \mathrm{M}$ \\
\hline 13 & $\mathrm{Fe}(\mathrm{II})_{\mathrm{aq}},+\mathrm{P}(\mathrm{PIPES})$ & 0.50 & 6.5 & $\mathrm{~F}>>\mathrm{L}$ & $\mathrm{F}>>\mathrm{L}$ & $\mathrm{L}>>\mathrm{M}$ \\
\hline
\end{tabular}

$2 \mathrm{LF}, 2$ line ferrihydrite ${ }^{\mathrm{a}}$; $6 \mathrm{LF}, 6$ line ferrihydrite ${ }^{\mathrm{a}} ; \mathrm{F}$, undifferentiated ferrihydrite; L, lepidocrocite; $\mathrm{G}$, goethite; $\mathrm{G}^{*}$, incipient goethite; $\mathrm{M}$, magnetite; $\mathrm{M}^{*}$, incipient magnetite.

2LF and 6LF not discernable from one-another by capillary XRD used for $\mathrm{Fe}(\mathrm{II})_{\mathrm{aq}}$ experiments.

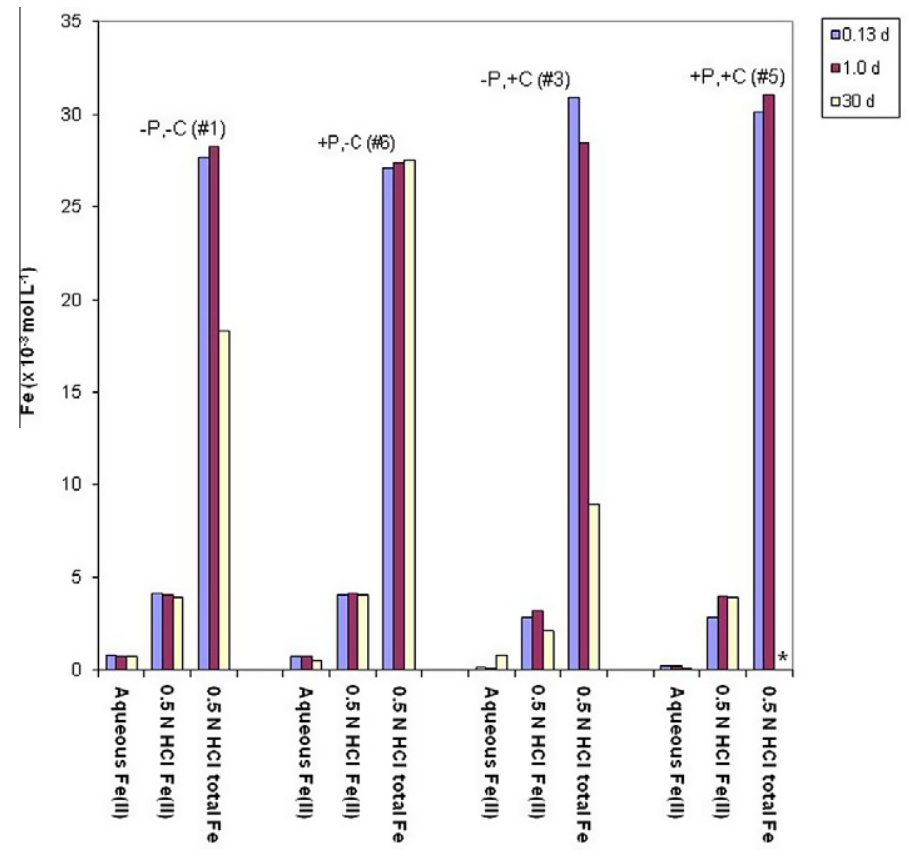

Fig. 1. Aqueous $\mathrm{Fe}(\mathrm{II}), 0.5 \mathrm{~N} \mathrm{HCl} \mathrm{Fe}(\mathrm{II})$, and $\mathrm{Fe}_{\text {total }}$ of 2-line Si-ferrihydrite reacted with $\mathrm{AH}_{2} \mathrm{DS}$ at $\mathrm{Fe}(\mathrm{II})_{\text {equiv }} / \mathrm{Fe}(\mathrm{III})=0.11$. The experiment numbers in Table 1 are noted. ${ }^{*}$ Total $\mathrm{Fe}$ analysis at $30 \mathrm{~d}$ not available. 
Rapid II microdiffraction system was used in transmission mode. $\mathrm{Cu} \mathrm{K} \alpha$ X-rays were generated using a $1200 \mathrm{~W}$ rotating anode source and collimated to $100 \mu \mathrm{m}$ on the capillary surface, with diffraction pattern collection onto a 2-D detector. The capillary tubes and water contribute to the diffraction pattern and must be considered (Figs. EA-1 and EA-2). The JADE+, V5 (Materials Data Inc., Livermore, California) software package was used for data analysis.

Scanning electron microscopy (SEM) was performed on powder samples using a FEI Helios 600 Dual Beam spectrometer operating at $5 \mathrm{keV}$ at $3-4 \mathrm{~mm}$ working distance fitted with secondary and backscatter electron detectors. High-resolution TEM analysis was carried out on a Jeol JEM 2010 microscope fitted with a $\mathrm{LaB}_{6}$ filament and an acceleration voltage of $200 \mathrm{kV}$. All images were recorded using a $1 \times 1 \mathrm{~K} \mathrm{CCD}$ camera and processed using Digital Micrograph (Gatan, USA). Lattice plane space was measured using the selected area electron diffraction (SAED) method. The camera constant of the microscope was calibrated using an evaporated Al polycrystalline thin film, which yields an overall measurement accuracy within the error of $1.4 \%$.

\section{RESULTS}

\subsection{General observations}

The reaction of either $\mathrm{AH}_{2} \mathrm{DS}$ or $\mathrm{Fe}(\mathrm{II})_{\mathrm{aq}}$ with 2-line ferrihydrite in PIPES buffer produced 6-line ferrihydrite, lepidocrocite, goethite, or magnetite as products (Table 2).

Lepidocrocite was most common, especially with $\mathrm{Fe}(\mathrm{II})_{\mathrm{aq}}$ as the reactant, where it formed rapidly in the absence of $\mathrm{P}$. Goethite was observed with $\mathrm{AH}_{2} \mathrm{DS}$ primarily when bicarbonate was present in the media (e.g., \#2 and \#3). Siderite was not observed when bicarbonate was present under the experimental conditions used. Magnetite was observed with both reductants at the highest $\mathrm{Fe}(\mathrm{II})_{\text {equiv }} /$ $\mathrm{Fe}(\mathrm{III})$ ratios (\#7, \#8, \#12). P suppressed reductive recrystallization at all reductant concentrations (\#4, \#5, \#9, \#11), and was especially inhibitory to magnetite formation by $\mathrm{Fe}(\mathrm{II})_{\mathrm{aq}}(\# 13)$. The final $\mathrm{pH}$ of the experiments varied by $1.5 \mathrm{U}$ (Table 2) with the lowest values observed for experiments with $\mathrm{Fe}(\mathrm{II})_{\mathrm{aq}}$. Details follow where results are presented in terms of the $\mathrm{Fe}(\mathrm{II})_{\text {equiv }} / \mathrm{Fe}(\mathrm{III})$ ratio (Table 1).

\section{2. $\mathrm{AH}_{2} \mathrm{DS}$ reacted with 2 -line $\mathrm{Si}$-ferrihydrite}

\subsubsection{Ferrihydrite transformation with $\mathrm{Fe}(\mathrm{II})_{\text {equiv }}$ I $\mathrm{Fe}(\mathrm{III})=0.11$}

$\mathrm{AH}_{2} \mathrm{DS}$ reacted (oxidized) to completion with ferrihydrite within $0.13 \mathrm{~d}$ as confirmed by UV-VIS absorption spectroscopy (not shown). In all four treatments, 10-15\% of the initially added Fe(III) was reduced within this time period (e.g., $0.5 \mathrm{~mol} \mathrm{~L}^{-1} \mathrm{HCl} \mathrm{Fe(II);} \mathrm{Fig.} \mathrm{1).} \mathrm{The} \mathrm{oxidation}$ of $\mathrm{AH}_{2} \mathrm{DS}$ to AQDS is a two-electron transfer reaction that is coupled, in this case, to the heterogeneous reduction of ferrihydrite $\mathrm{Fe}$ (III) to $\mathrm{Fe}(\mathrm{II})$ (Burgos et al., 2003). Aqueous $\mathrm{Fe}(\mathrm{II})$ constituted $10-20 \%$ of the $0.5 \mathrm{~mol} \mathrm{~L}^{-1} \mathrm{HCl} \mathrm{Fe}(\mathrm{II})$ [e.g., $\mathrm{Fe}(\mathrm{II})_{\text {total }}$. Sorbed $\mathrm{Fe}(\mathrm{II})$, calculated as the difference between $0.5 \mathrm{~mol} \mathrm{~L}^{-1} \mathrm{HCl} \mathrm{Fe}(\mathrm{II})$ and aqueous $\mathrm{Fe}(\mathrm{II})$, was $\sim 10 \%$ of the total solid Fe. The pretreatment of 2-line ferrihydrite with $\mathrm{P}(2 \%)$ and/or $\mathrm{C}(2.4 \%)$ had little effect on the extent or timing of 2-line ferrihydrite reduction (Fig. 1). Total $0.5 \mathrm{~mol} \mathrm{~L}^{-1} \mathrm{HCl}$ extractable $\mathrm{Fe}$ decreased at $30 \mathrm{~d}$ in those samples where appreciable crystalline $\mathrm{Fe}(\mathrm{III})$ oxide formation was observed $[-\mathrm{P}-\mathrm{C}(\# 1) ;-\mathrm{P}+\mathrm{C}(\# 3)]$. For the others (e.g., $+\mathrm{P}$ treatments), $\mathrm{Fe}(\mathrm{II})$ concentrations (aqueous and $0.5 \mathrm{~mol} \mathrm{~L}^{-1} \mathrm{HCl}$-extracted) and $0.5 \mathrm{~mol} \mathrm{~L}^{-1} \mathrm{HCl}$ total $\mathrm{Fe}$ were similar at all the time points. Crystalline $\mathrm{Fe}(\mathrm{III})$ oxides, such as goethite and lepidocrocite, are less soluble in weak acid than ferrihydrite (Fredrickson et al., 1998).
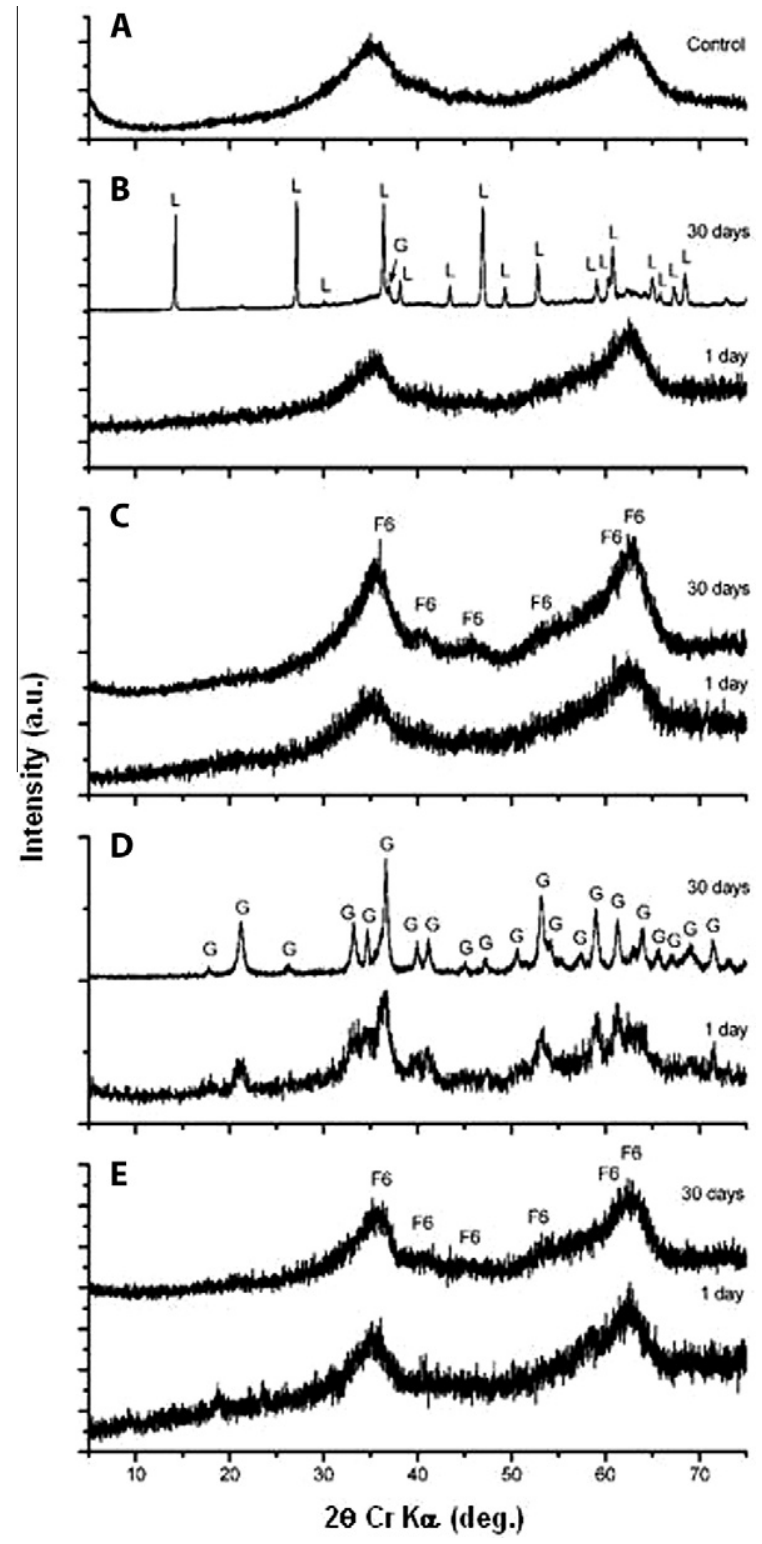

Fig. 2. Reaction products from the $\mathrm{Fe}(\mathrm{II})_{\text {equiv }} / \mathrm{Fe}(\mathrm{III})=0.11$ experiment series (A) Control; (B) $-\mathrm{P}-\mathrm{C}(\# 1)$; (C) $+\mathrm{P}-\mathrm{C}(\# 4)$; (D) $-\mathrm{P}+\mathrm{C}(\# 3)$; and $(\mathrm{E})+\mathrm{P}+\mathrm{C}(\# 5)$. Lepidocrocite $(\mathrm{L})$, goethite $(\mathrm{G})$, and 6-line ferrihydrite (F6) are labeled. 
In spite of similar reduction extents and aqueous and sorbed $\mathrm{Fe}(\mathrm{II})$ concentrations, the mineralogic nature of the reductive transformation products varied with pretreatment. Without P or C (\#1), 2-line ferrihydrite slowly trans- formed to lepidocrocite (Fig. 2B). The slow nature of the transformation reaction was evident from a comparison of the 1 and $30 \mathrm{~d}$ XRD patterns (Fig. 2B). The $1 \mathrm{~d}$ pattern was virtually identical to that of the control (Fig. 2A), in
A

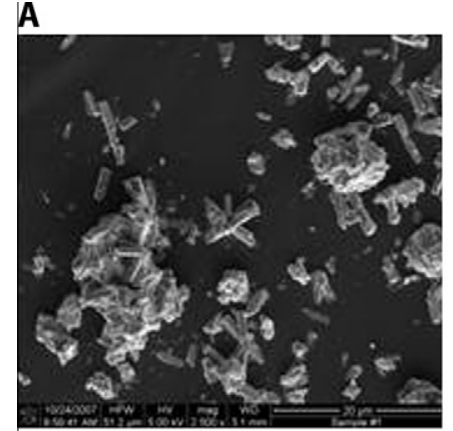

C

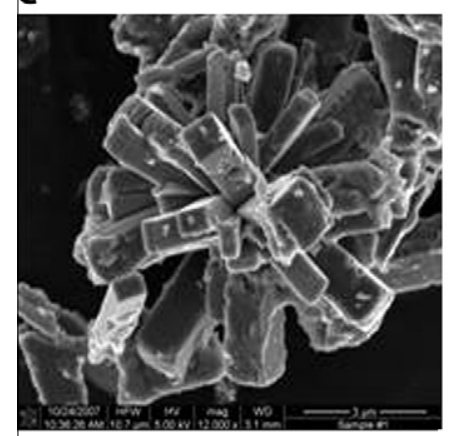

E

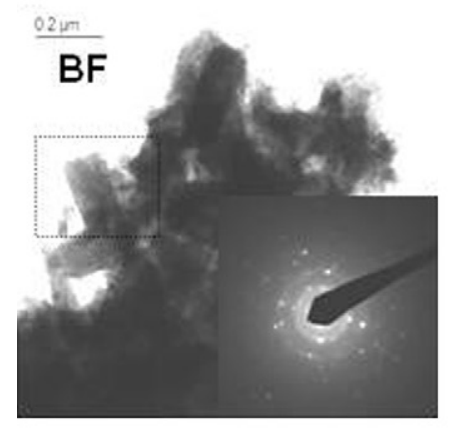

G

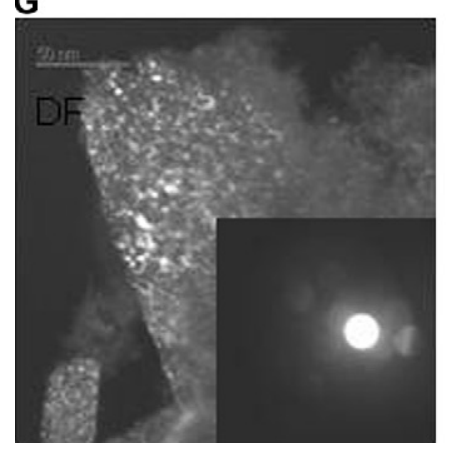

B

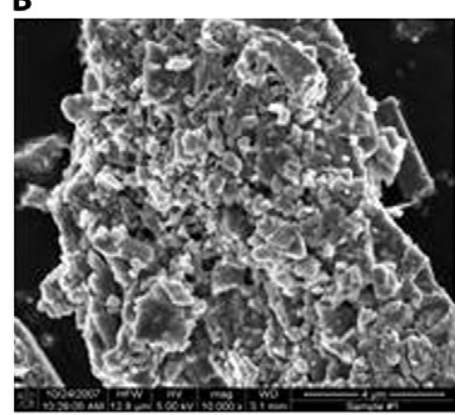

D

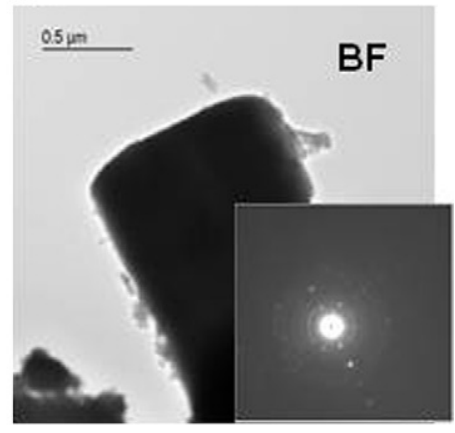

$\mathbf{F}$

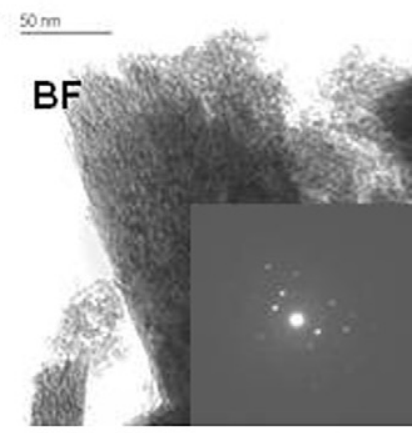

H

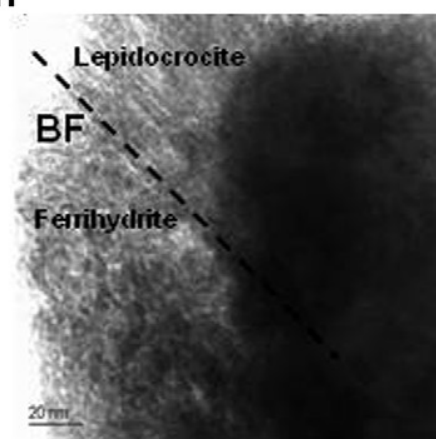

Fig. 3. SEM $(\mathrm{A}-\mathrm{C})$ and transmission electron micrographs $(\mathrm{D}-\mathrm{H})$ of 2 -line Si-ferrihydrite reacted with $\mathrm{AH}_{2} \mathrm{DS}\left[\mathrm{Fe}(\mathrm{II})_{\mathrm{equiv}} / \mathrm{Fe}(\mathrm{III})\right]=0.11$ without $\mathrm{P}$ or $\mathrm{C}(30 \mathrm{~d})$. The product consisted of lepidocrocite laths (A), plates (B), and rosettes (C) intermixed with 2-line Si-ferrihydrite. The TEM-SAED (D-F inserts) and nanodiffraction (insert G) of the product phases were consistent with compact lepidocrocite (PDF \#044-1415) crystals relatively free of ferrihydrite association (D), and porous lepidocrocite crystals with ferrihydrite interface (E-H). The bright field (BF) and dark field (DF) images shown in (F) and (G) correspond to the region highlighted in (E). 
spite of significant sorbed Fe(II) (e.g., 10\%; Fig. 1). The $+\mathrm{P}$ (\#6) was partially transformed to $\mathrm{Fe}(\mathrm{II})$-sorbed, 6-line ferrihydrite over $30 \mathrm{~d}$ (Fig. 2C), with no hints of lepidocrocite or goethite. Ferrihydrite pretreatment with $\mathrm{C}$ facilitated transformation to crystalline $\mathrm{Fe}(\mathrm{III})$-oxides (Table 2 and Fig. 2D). The product identity was dictated by the $\mathrm{C}$ concentration. Lepidocrocite formed in the low $+\mathrm{C}$ treatment $(0.8 \%$; \#2, not shown), whereas goethite precipitated when $\mathrm{C}$ was present at $2.4 \%$ (\#3, Fig. 2D). The effect of $\mathrm{C}$ was, however, suppressed by $2 \% \mathrm{P}$ (\#5, Fig. 2E), yielding 6-line ferrihydrite as the product.

SEM analysis (Fig. 3) of the lepidocrocite/ferrihydrite mixture obtained after $30 \mathrm{~d}$ without $\mathrm{P}$ or $\mathrm{C}$ (\#1, Fig. 2B) revealed the presence of lepidocrocite in various morphologies intermixed with 2-line ferrihydrite. Lepidocrocite existed in $2-5 \mu \mathrm{m}$ lath-like and tabular morphologies. The crystallites were both isolated (Fig. 3A and B) and present as rosettes (Fig. 3A-C). Dark field (DF) and bright field (BF) TEM imaging as well as SAED and nanodiffraction analyses revealed two distinct lepidocrocite crystal formations: (i) compact (Fig. 3D) and (ii) porous (Fig. 3E-G). High-resolution TEM imaging of the porous lepidocrocite/ferrihydrite region further revealed an apparent interface between lepidocrocite and ferrihydrite (Fig. 3H).

The nature of 2- and 6-line ferrihydrite and their spatial association in the $+\mathrm{P}-\mathrm{C}$ system (\#4, Fig. 2C) was further investigated using BF and DF TEM and associated SAED measurements (Fig. 4). Bright spots in the DF images were attributed to more crystalline 6-line ferrihydrite that was randomly dispersed through the 2-line ferrihydrite. The 2to 6-line ferrihydrite ratio estimated by TEM was 30:70, which was in qualitative agreement with the XRD pattern (Fig. 2C).

SEM and TEM analysis (Fig. 5) of the goethite/ferrihydrite mixture from the $-\mathrm{P}+\mathrm{C}(2.4 \%)$ treatment $(\# 3$, Fig. 2D) revealed the presence of acicular goethite (20 $200 \mathrm{~nm}$ ) with individual and intergrown crystallites (Fig. 5A and B), that were intimately associated with ferrihydrite (Fig. 5C-E). It is unclear whether the observed goethite-ferrihydrite association is characteristic of the mineral product, or an artifact of sample preparation that included drying.

Mössbauer spectroscopy measurements were performed to characterize the sorbed $\mathrm{Fe}(\mathrm{II})$ that resulted from heterogeneous reaction with $\mathrm{AH}_{2} \mathrm{DS}$. The $\mathrm{Fe}(\mathrm{II})$-containing 2and 6-line ferrihydrite mixture that was free of goethite or lepidocrocite [+P-C; \#4; Fig. 2C] and another containing lepidocrocite, goethite, and ferrihydrite $[-\mathrm{P}+\mathrm{C}(2.4 \%)$; \#3; Fig. 2D) were analyzed. The derived Mössbauer parameters of the control Si-ferrihydrite [center shift, $\{\mathrm{CS}=0.46 \mathrm{~mm} /$ $\mathrm{s}$, sensitive to oxidation state; and average quadrupole splitting, $\{\mathrm{QS}=0.83 \mathrm{~mm} / \mathrm{s}\}$, sensitive to coordination environment] at RT (not shown) and $77 \mathrm{~K}$ (Fig. 6A) agreed well with that of 2-line ferrihydrite (Murad and Cashion, 2004).

The RT spectrum of the Fe(II)-ferrihydrite $(+\mathrm{P}-\mathrm{C}$; \#4) displayed a large central doublet due to residual ferrihydrite
A

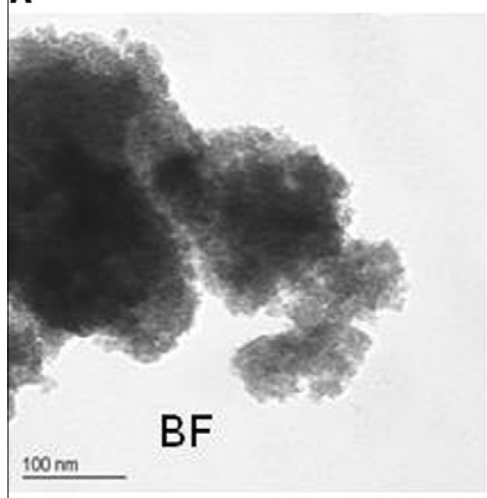

D

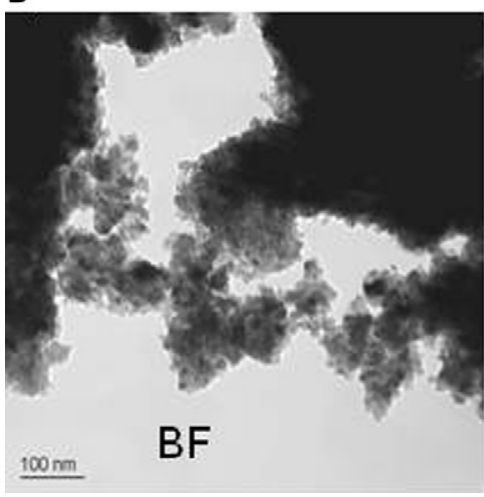

B

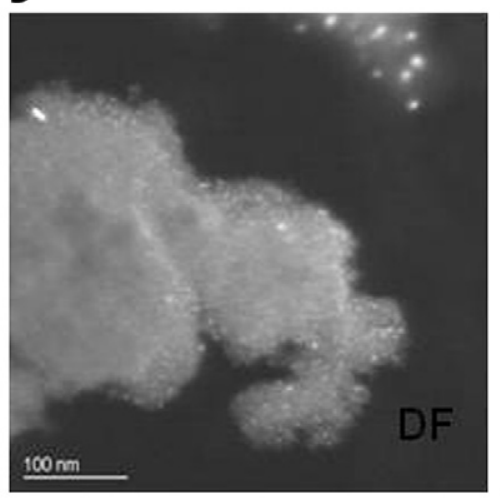

E

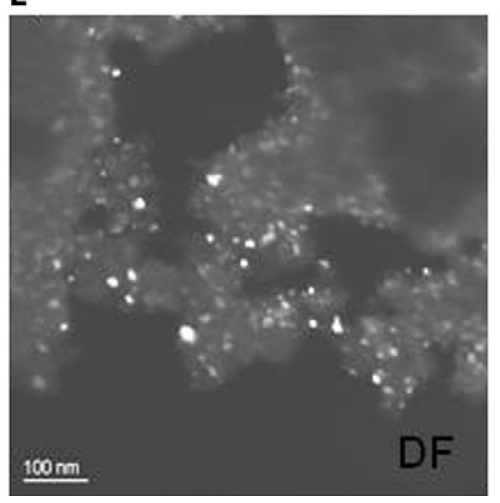

C

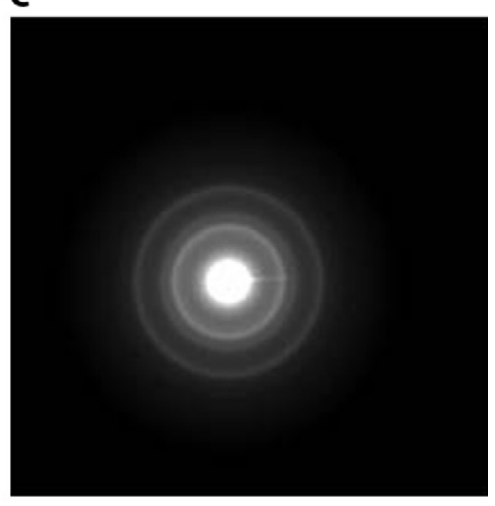

$\mathbf{F}$

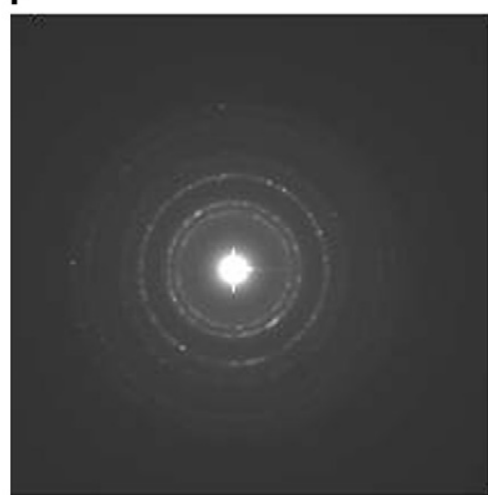

Fig. 4. TEM and TEM-SAED of 2-line Si-ferrihydrite reacted for 30 days with $\mathrm{AH}_{2} \mathrm{DS}(+\mathrm{P}-\mathrm{C})$ displaying partial transformation of 2-line ferrihydrite to 6-line ferrihydrite. The bright spots in dark field (DF) images result from 6-line ferrihydrite (B and E). The ring pattern in (C) was characteristic of 2-line ferrihydrite, while that in (F) was due to 6-line ferrihydrite. 
A

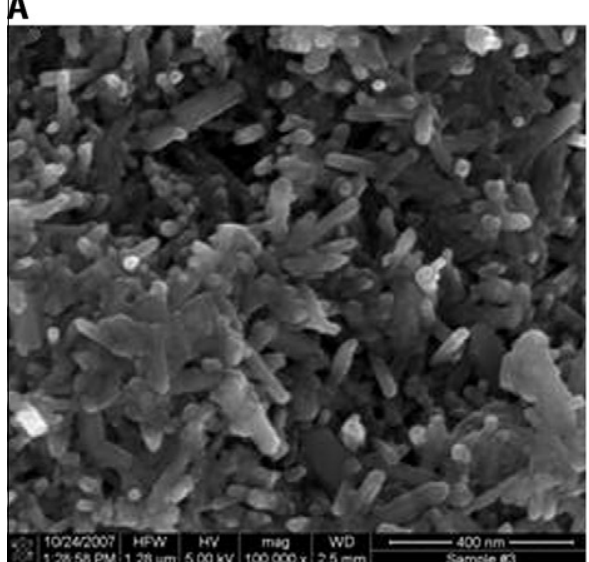

C

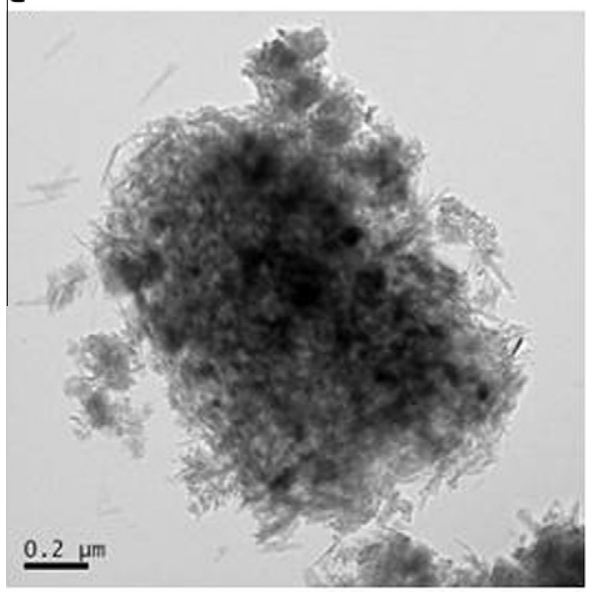

B

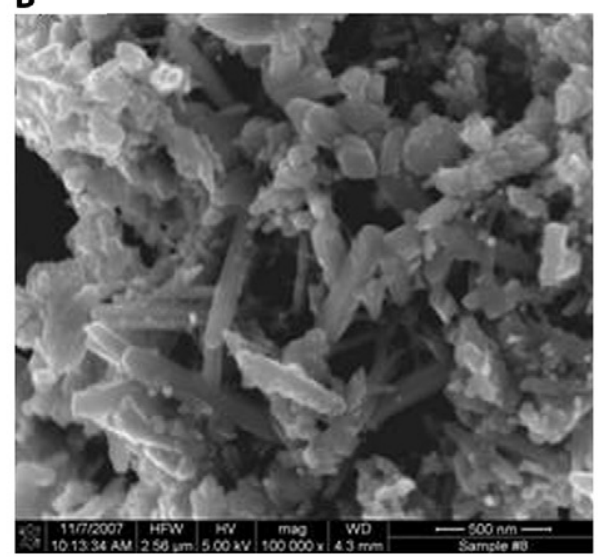

D

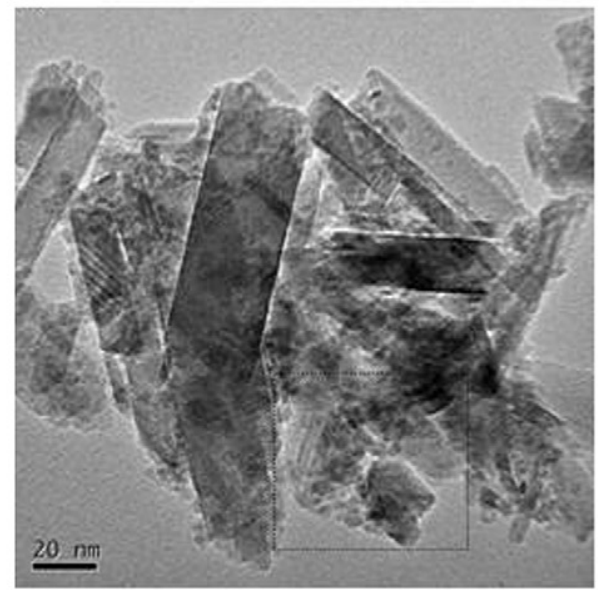

$\mathbf{E}$

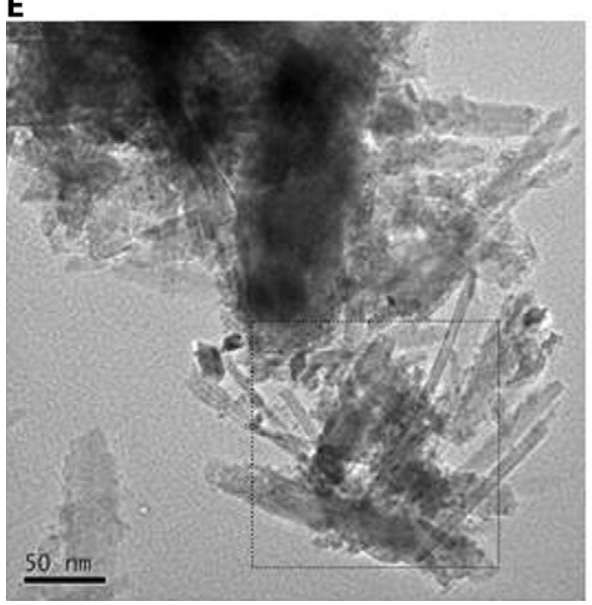

Fig. 5. SEM (A and B) and TEM bright field (C-E) of 2-line Si-ferrihydrite reacted for 30 days with $\mathrm{AH}_{2} \mathrm{DS}$ in presence of $\mathrm{C}(2.4 \%)$. The highlighted regions in TEM (D and E) revealed association of acicular goethite crystals with ferrihydrite.

( $\sim 90 \%$ of spectral area), and a small, broad doublet from sorbed $\mathrm{Fe}(\mathrm{II})\left(\sim 10 \%\right.$; indicated by ${ }^{*}$ in Fig. $\left.6 \mathrm{~B}\right)$. The $77 \mathrm{~K}$ spectrum, on the other hand, displayed a distinct $\mathrm{Fe}(\mathrm{II})$ doublet, a Fe(III) doublet, and a Fe(III) sextet (Fig. 6C). The spectral differentiation of $\mathrm{Fe}(\mathrm{III})$ at $77 \mathrm{~K}$ was consistent with the presence of both 2- and 6-line ferrihydrite (Kukkadapu et al., 2003). The contribution of the Fe(III)sextet to the spectrum $(\sim 35 \%)$, however, was lower than the estimated 6-line ferrihydrite concentration from XRD and TEM $(\sim 70 \%)$. This discrepancy may result from decreased inter-particle magnetic interactions or hyperfine fields due to $\mathrm{P}$ surface complexation as reported for Si-doped ferrihydrites (Zhao et al., 1996). The explicit contributions of the 2- and 6-line components to the spectra were consequently not modeled because of these uncertainties. 

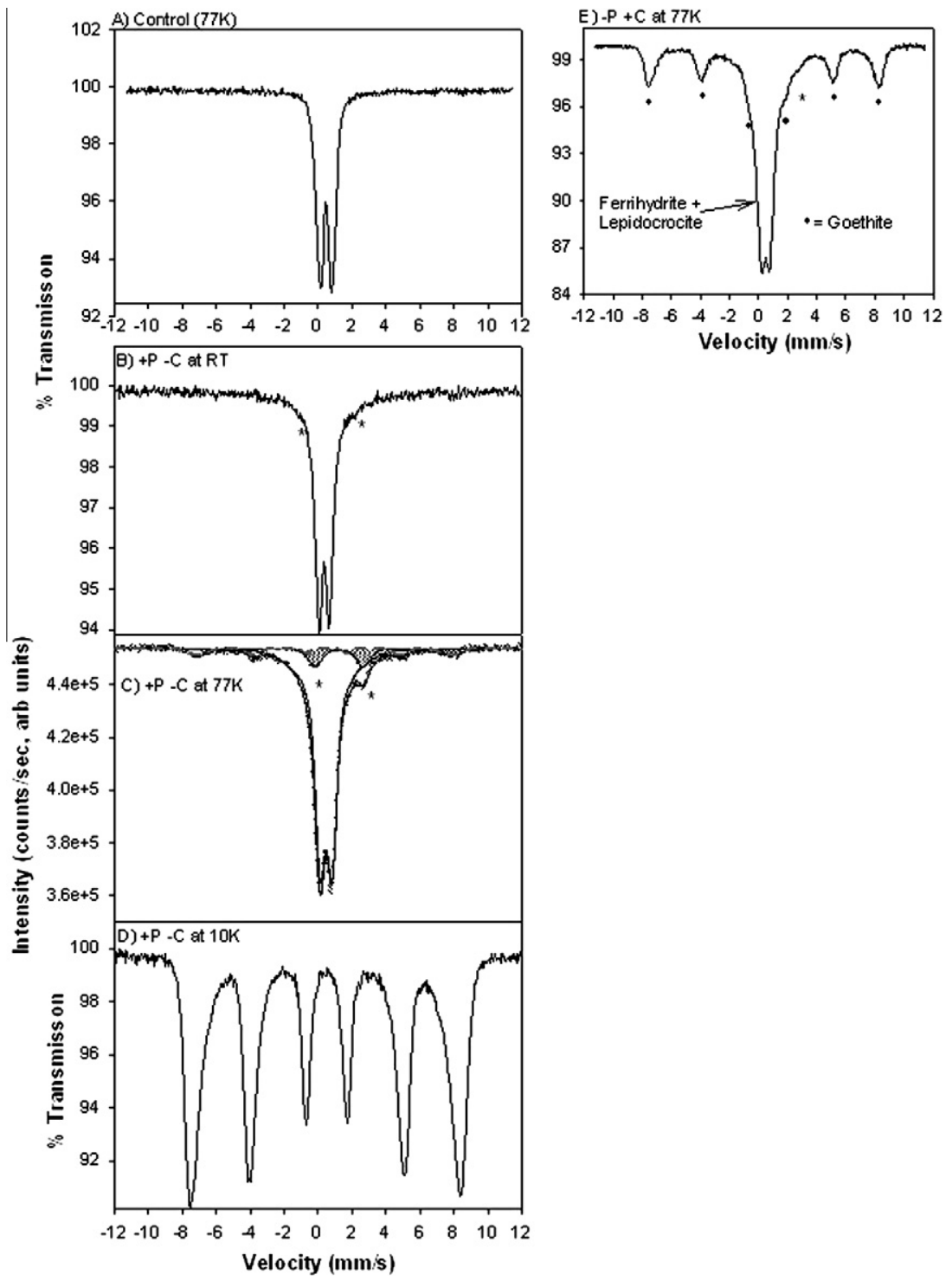

Velocity $(\mathrm{mm} / \mathrm{s})$

Fig. 6. Mössbauer spectra of control at $77 \mathrm{~K}(\mathrm{~A})$, and spectra of 2-line Si-ferrihydrite reacted for 30 days with $\mathrm{AH} \mathrm{H}_{2} \mathrm{DS}$ and $+\mathrm{P}-\mathrm{C}$ (\#4) at various temperatures (B-D) or $-\mathrm{P}+\mathrm{C}(\# 3)(\mathrm{E})$. Fe(II) doublet peaks are indicated by ${ }^{*}$ in $(\mathrm{B}),(\mathrm{C})$, and (E). The Fe(II) doublet peaks in (C) are also textured with dots.

The ferrous doublet contribution to the $+\mathrm{P}-\mathrm{C}$ spectra (Fig. 6B and C) was consistent with the $0.5 \mathrm{~mol} \mathrm{~L}^{-1} \mathrm{HCl}$ extractable $\mathrm{Fe}(\mathrm{II})$ concentration $(\sim 10 \%)$. The $\mathrm{Fe}(\mathrm{II})$ spectral area was higher than the maximum amount of vivianite $(3 \%)$ that could form, given the $\mathrm{P} /(\mathrm{Fe}+\mathrm{P})$ ratio of $2 \%$ used in the experiment (Table 1). The derived Fe(II) Mössbauer parameters were also different from those of vivianite (e.g., Kukkadapu et al., 2004; Murad and Cashion 2004). The $\mathrm{Fe}$ (II) and ferrihydrite phases magnetically ordered at $10 \mathrm{~K}$ (Fig. 6D). The RT and $77 \mathrm{~K}$ Mössbauer parameters [asymmetric $\mathrm{QS}$ distribution and $[\mathrm{QS} \mid]$ and the $10 \mathrm{~K}$ temperature behavior implied that the sorbed $\mathrm{Fe}(\mathrm{II})$ was: (i) distributed over a range of sites (Rancourt and Ping, 1991), (ii) in distorted octahedral coordination (Greenwood and Gibb, 1971), and (iii) strongly bound as an inner-sphere complex to $\mathrm{Fe}(\mathrm{III})-\mathrm{O}$ sites (Greenwood and Gibb, 1971). Discrete Mössbauer peaks characteristic of $\mathrm{Fe}(\mathrm{II})$ were also evident in the spectra of the lepidocrocite/goethite/ferrihydrite mixture $(-\mathrm{P}+\mathrm{C} ; \# 3$, Fig. 6E). Quantification and interpretation of the $\mathrm{Fe}(\mathrm{II})$ signal for this treatment was complicated by low signal strength and peak overlap with the ferric doublet and sextet.

\subsubsection{Ferrihydrite transformation with $\mathrm{Fe}(\mathrm{II})_{\text {equiv }}$ l $\mathrm{Fe}(\mathrm{III})=0.54$}

The $\mathrm{Fe}(\mathrm{II})_{\text {equiv }} / \mathrm{Fe}(\mathrm{III})$ ratio of this experiment was approximately equal to that of magnetite after the heterogeneous reaction with $\mathrm{AH}_{2} \mathrm{DS}$ was complete (e.g., 1:2). Approximately $33 \%$ of the total $\mathrm{Fe}$ was reduced in $1 \mathrm{~d}$ for both experiments (\#6 and \#7), consistent with complete $\mathrm{AH}_{2} \mathrm{DS}$ oxidation (Fig. 7A). Stronger acid $\left(5 \mathrm{~mol} \mathrm{~L}^{-1}\right.$ $\mathrm{HCl}$ ) was used to dissolve the crystalline products that formed under these conditions. Both the $-\mathrm{P}$ and $+\mathrm{P}$ experiments displayed almost identical aqueous and extractable 

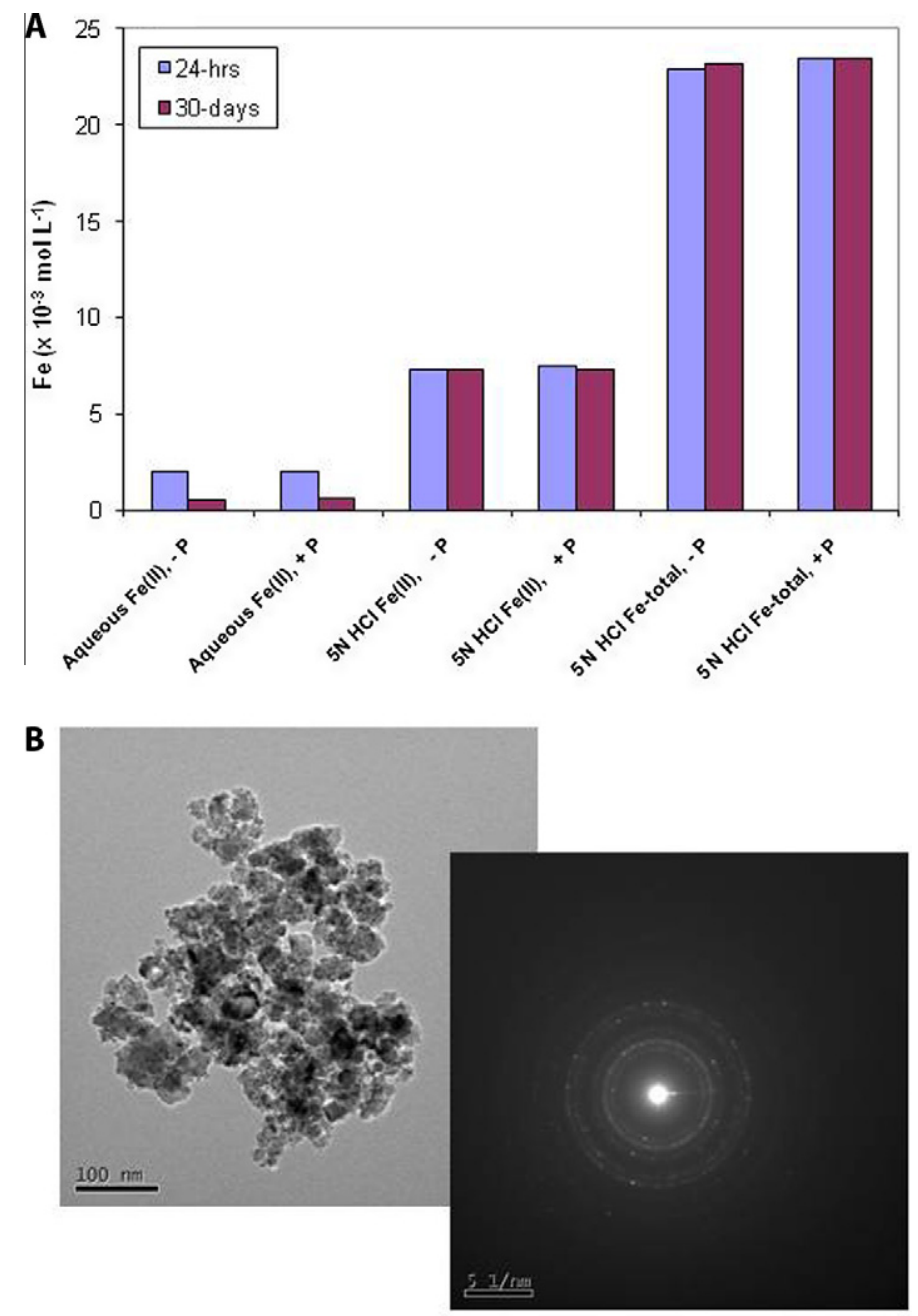

Fig. 7. Iron concentrations (A) after 1 and $30 \mathrm{~d}$ of $\mathrm{AH}_{2} \mathrm{DS}$ reaction with ferrihydrite at $\mathrm{Fe}(\mathrm{II})_{\text {equiv }} / \mathrm{Fe}(\mathrm{III})=0.5$. Product morphology (30 d) and selected area diffraction (SAED) by TEM (B).

Fe. Aqueous $\mathrm{Fe}(\mathrm{II})$ represented $23 \%$ of the $\mathrm{Fe}(\mathrm{II})$ pool after $1 \mathrm{~d}$, and this decreased by a factor of 2.5 over $30 \mathrm{~d}$. Little change in extractable Fe was noted between 1 and $30 \mathrm{~d}$.

Incipient magnetite was observed in both experiments after $1 \mathrm{~d}$, and this crystallized to magnetite in $30 \mathrm{~d}$ (Fig. 8). Phosphate had no apparent effect on the $30 \mathrm{~d}$ product of reaction. The final product was stoichiometric magnetite in both treatments (\#6 and \#7) as determined by both chemical extraction [e.g., 30\% Fe(II) in Fig. 7A] and Mössbauer analysis (not shown). There was no evident crystalline precursor. The magnetite existed as irregular 20-45 nm crystallites without distinct morphology as determined by TEM/SAED (Fig. 7B). A solid-state transformation reaction was implied.

\section{3. $\mathrm{Fe}(\mathrm{II})_{\mathrm{aq}}$ reacted with 2 -line $\mathrm{Si}$-ferrihydrite}

\subsubsection{Aqueous $\mathrm{Fe}(\mathrm{II})$ concentrations}

The $\mathrm{Fe}(\mathrm{II})$ experiments were performed with $10 \times$ $10^{-3} \mathrm{~mol} \mathrm{~L}^{-1}$ ferrihydrite and involved contact with 0.5 , 3.3 , and $5.0 \times 10^{-3} \mathrm{~mol} \mathrm{~L}^{-1} \mathrm{Fe}(\mathrm{II})_{\mathrm{aq}}$ both with and without
$\mathrm{P}$ (Table 1). All of these experiments supported significant $\mathrm{Fe}(\mathrm{II})_{\mathrm{aq}}$ concentrations during their course (Fig. 9). While there were temporal changes in $\mathrm{Fe}(\mathrm{II})_{\mathrm{aq}}$ that varied with treatment, there were no consistent trends, and the degree of variation was small. Ferrous iron adsorption, and hence electron transfer to ferrihydrite, was rapid and effectively complete by the first measurement point $(0.13 \mathrm{~d})$. The degree of $\mathrm{Fe}(\mathrm{II})$ adsorption was approximately $55 \%$ for $0.5 \times 10^{-3} \mathrm{~mol} \mathrm{~L}^{-1}$, and $15 \%$ for 3.3 and $5.0 \times 10^{-3}$ $\mathrm{mol} \mathrm{L}^{-1} \mathrm{Fe}(\mathrm{II})$. Consequently, most of the added $\mathrm{Fe}(\mathrm{II})_{\mathrm{aq}}$ remained in solution for the two highest concentrations.

\subsubsection{Ferrihydrite transformations}

The reductive transformation of Si-ferrihydrite was consistent across the $\mathrm{Fe}(\mathrm{II})$ concentration range studied (Figs. 10, 11 and EA-3). Quantification of residual ferrihydrite in these samples by XRD was more difficult than the powders because of water and capillary interferences (Figs. EA1 and EA-2). Changes to the intensity of the XRD peaks of all samples were minimal between 30 and $63 \mathrm{~d}$ (Figs. EA-3EA-5), indicating complete transformation of ferrihydrite by $30 \mathrm{~d}$. Moreover, there was no change in the product 


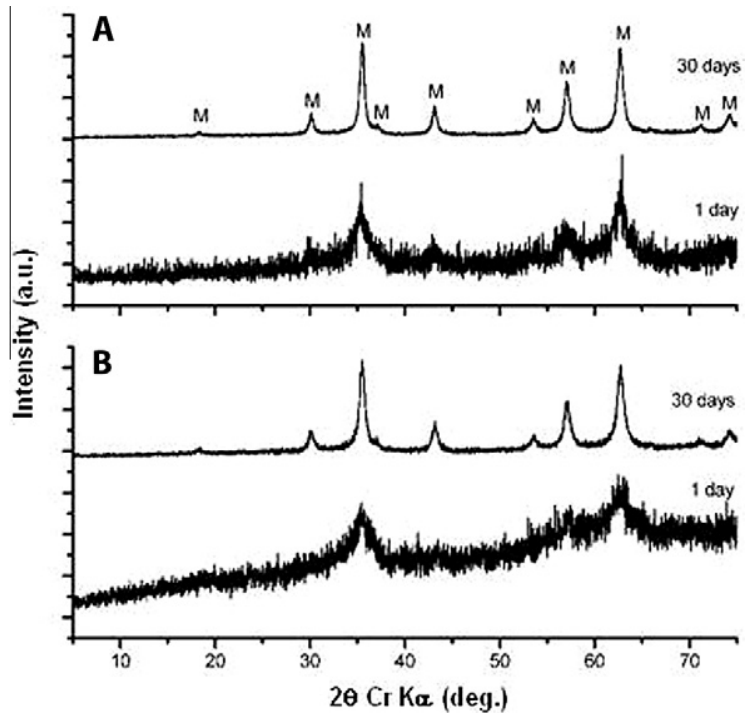

Fig. 8. Powder X-ray diffraction of dried mineral residues after 1 and $30 \mathrm{~d}$ of $\mathrm{AH}_{2} \mathrm{DS}$ reaction with ferrihydrite at $\mathrm{Fe}(\mathrm{II})_{\text {equiv }} /$ $\mathrm{Fe}(\mathrm{III})=0.54$. (A) $-\mathrm{P}-\mathrm{C}(\# 6)$ and $(\mathrm{B})+\mathrm{P}-\mathrm{C}(\# 7)$. Magnetite $(\mathrm{M})$ peaks are labeled.

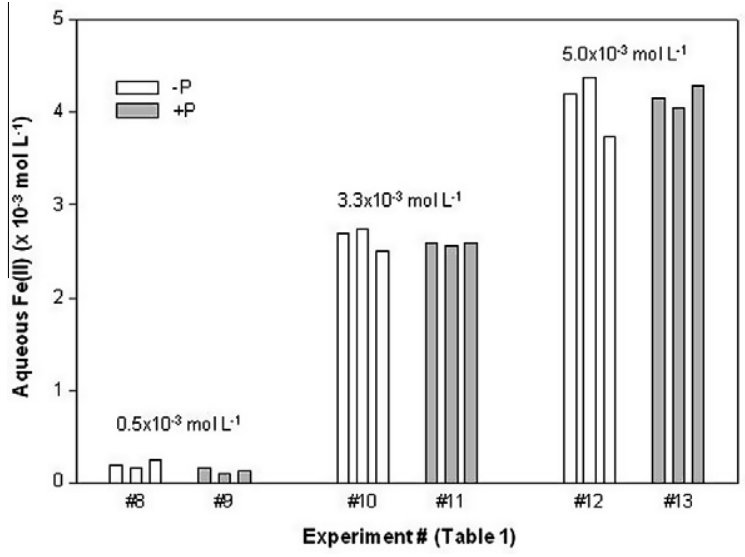

Fig. 9. Aqueous $\mathrm{Fe}(\mathrm{II})$ concentrations present in treatments \#8-13 as measured after $0.13,1.0$, and $30 \mathrm{~d}$ of contact. The ferrihydrite concentration was $10 \times 10^{-3} \mathrm{~mol} \mathrm{~L}^{-1}$ and the initial $\mathrm{Fe}(\mathrm{II})_{\mathrm{aq}}$ concentrations were as noted.

phase assemblages between 30 and $63 \mathrm{~d}$, indicating reaction product stability over this time range.

Lepidocrocite formed rapidly in the absence of $\mathrm{P}$, with approximately $35 \%$ of the ferrihydrite transformed within $0.13 \mathrm{~d}$ for all three $\mathrm{Fe}(\mathrm{II})$ concentrations. At $0.5 \times$ $10^{-3} \mathrm{~mol} \mathrm{~L}^{-1} \mathrm{Fe}(\mathrm{II})_{\mathrm{aq}}$, lepidocrocite formation increased by 1.5 times between 0.13 and $1 \mathrm{~d}$, and another 2 times between 1 and $30 \mathrm{~d}$ (Fig. 10). Product lepidocrocite exhibited tabular morphology $(\sim 1 \mu \mathrm{m})$ with predominant $\left\{\begin{array}{lll}0 & 1 & 0\end{array}\right\}$ faces (Fig. 12), as described by Schwertmann and Cornell (2000). The lath-like rosettes and porous structures observed with $\mathrm{AH}_{2} \mathrm{DS}$ (Fig. 3) were not evident here. At $5.0 \times 10^{-3} \mathrm{~mol} \mathrm{~L}^{-1}$, lepidocrocite formation was static between 0.13 and $1 \mathrm{~d}$, but increased by 1.5 times over $30 \mathrm{~d}$.

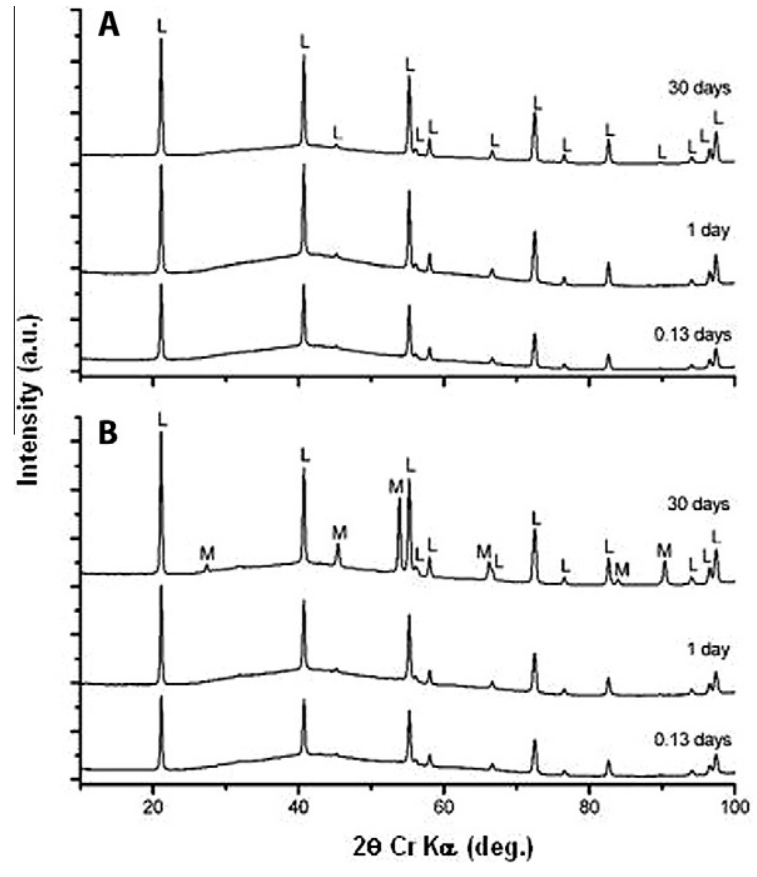

Fig. 10. Capillary X-ray diffractograms of moist mineral residue from the reaction of $0.5 \times 10^{-3} \mathrm{~mol} \mathrm{~L}^{-1} \mathrm{Fe}(\mathrm{II})_{\mathrm{aq}}$ (A) or $5.0 \times 10^{-3} \mathrm{~mol} \mathrm{~L}^{-1} \mathrm{Fe}(\mathrm{II})_{\mathrm{aq}}$ (B) with $10 \times 10^{-3} \mathrm{~mol} \mathrm{~L}^{-1} \mathrm{Si}$-ferrihydrite. Diffraction peaks from lepidocrocite (L) and magnetite (M) are labeled.

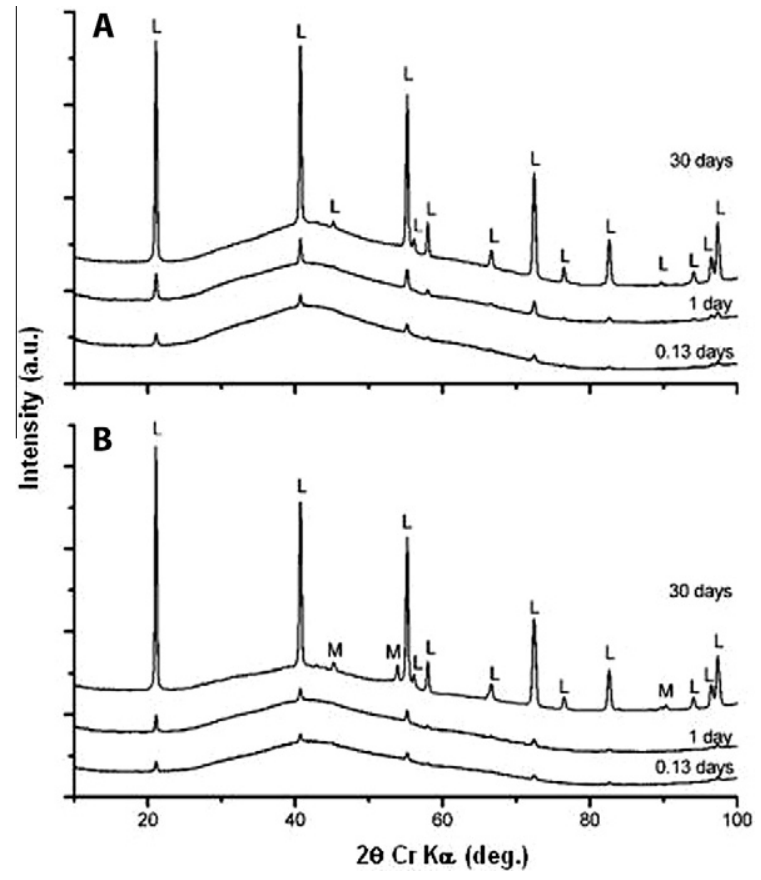

Fig. 11. Capillary X-ray diffractograms of moist mineral residue from the reaction of $0.5 \times 10^{-3} \mathrm{~mol} \mathrm{~L}^{-1} \mathrm{Fe}(\mathrm{II})_{\mathrm{aq}}+0.2 \times 10^{-3}$ $\mathrm{mol} \mathrm{L}^{-1} \mathrm{PO}_{4(\mathrm{aq})}$ (A), or $5.0 \times 10^{-3} \mathrm{~mol} \mathrm{~L}^{-1} \mathrm{Fe}(\mathrm{II})+0.2 \times$ $10^{-3} \mathrm{~mol} \mathrm{~L}^{-1} \mathrm{PO}_{4(\mathrm{aq})}$ (B) with $10 \times 10^{-3} \mathrm{~mol} \mathrm{~L}^{-1}$ Si-ferrihydrite. Diffraction peaks from lepidocrocite $(\mathrm{L})$ and magnetite $(\mathrm{M})$ are labeled. 


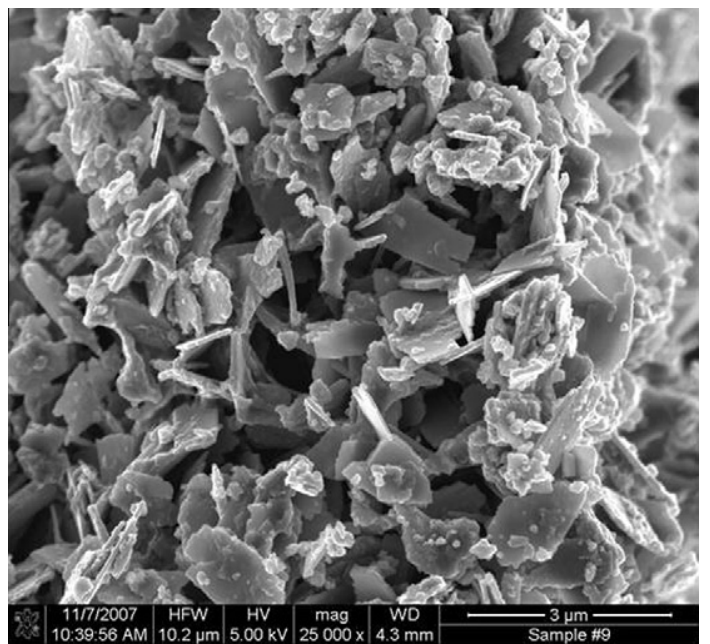

Fig. 12. SEM micrograph of tabular lepidocrocite produced from the reaction of $\mathrm{Fe}(\mathrm{II})_{\mathrm{aq}}$ with Si-ferrihydrite.

Magnetite formation commenced after $1 \mathrm{~d}$ at $5.0 \times$ $10^{-3} \mathrm{~mol} \mathrm{~L}^{-1} \mathrm{Fe}(\mathrm{II})$, and continued in parallel to, but with a faster rate than lepidocrocite to $30 \mathrm{~d}$ (Fig. 10). The mineralization trend for $3.3 \times 10^{-3} \mathrm{~mol} \mathrm{~L}^{-1} \mathrm{Fe}(\mathrm{II})$ was nearly identical to $5.0 \times 10^{-3} \mathrm{~mol} \mathrm{~L}^{-1}$, except that lesser amounts of magnetite were formed after $30 \mathrm{~d}$ (Fig. EA-6).

Phosphate had a comparable effect on ferrihydrite transformation at all $\mathrm{Fe}(\mathrm{II})_{\mathrm{aq}}$ concentrations (Fig. 11 and EA-6). The formation of lepidocrocite was dramatically slowed by $\mathrm{P}$ over the first day of reaction. After this inhibition period, lepidocrocite formation proceeded to yield final concentrations after $30 \mathrm{~d}$ that were comparable to the system without P. Magnetite formation was also inhibited by P. Magnetite existed only as a minor component after $30 \mathrm{~d}$ at $5.0 \times$ $10^{-3} \mathrm{~mol} \mathrm{~L}^{-1}$, and was not observed at $3.3 \times 10^{-3} \mathrm{~mol} \mathrm{~L}^{-1}$ (Fig. EA-6). Indeed, the $30 \mathrm{~d}$ diffraction pattern for 0.5 and $3.3 \times 10^{-3} \mathrm{~mol} \mathrm{~L}^{-1} \mathrm{Fe}(\mathrm{II})$ in the presence of $\mathrm{P}$ were virtually identical.

\section{DISCUSSION}

The research utilized a 2-line ferrihydrite preparation containing $2 \mathrm{~mol} \% \mathrm{Si}(0.02 \mathrm{~mol} \mathrm{Si}$ :mole Fe). Ferrihydrites with comparable $\mathrm{Si}$ concentrations are observed in terrestrial environments (Fortin et al., 1993; Tessier et al., 1996; Perret et al., 2000), with sorbed Si promoting their metastable persistence (Carlson and Schwertmann, 1981). Sorbed Si retards ferrihydrite recrystallization under oxic laboratory conditions (Anderson and Benjamin, 1985; Cornell et al., 1987; Cornell and Giovanoli, 1987), and yields ferrihydrite preparations free of crystalline impurities (Dyer et al., 2010). It was used here specifically to eliminate a parallel mineral transformation pathway of oxidative recrystallization. The total sorbed Si concentration $(0.02 \mathrm{~mol} \mathrm{Si}$ :mole $\mathrm{Fe})$ is well below site saturation, according to Dzombak and Morel (1990) (e.g., Type 2 sites at 0.2 mol:mol Fe). ATR-IR measurements of adsorbed silica on ferrihydrite at this surface loading indicate the presence of approximately $75 \%$ monomeric surface complexes (Swedlund et al., 2009). Increased surface load- ings beyond this value encourage surface polymerization, decreasing concentrations of the monomeric surface complex, and $\mathrm{Si}$ precipitation around aggregate surfaces (Swedlund et al., 2009; Dyer et al., 2010). While retarding oxidative recrystallization, we have observed no influence of sorbed $\mathrm{Si}$ at this concentration on reductive ferrihydrite mineralization in previous studies (Kukkadapu et al., 2004). We cannot, however, totally discount an effect. Unpublished studies by our laboratory reveal only slight differences in the fundamental reaction rate of $\mathrm{AH}_{2} \mathrm{DS}$ with fresh 2-line ferrihydrite precipitate and an identical preparation with $0.02 \mathrm{~mol} \mathrm{Si:mole} \mathrm{Fe.} \mathrm{In} \mathrm{contrast,} \mathrm{significantly} \mathrm{high-}$ er concentrations of coprecipitated Si (e.g., $0.68 \mathrm{~mol} \mathrm{Si:mole}$ $\mathrm{Fe}$ ) change the reductive mineralization behavior of ferrihydrite and suppresses its reactivity with $\mathrm{Fe}(\mathrm{II})_{\mathrm{aq}}$ (Jones et al., 2009).

\subsection{Comparison of reaction products from $\mathrm{AH}_{2} \mathrm{DS}$ and $\mathrm{Fe}(\mathrm{II})_{\mathrm{aq}}$ without $\mathrm{P}$}

Bioreduced AQDS $\left(\mathrm{AH}_{2} \mathrm{DS}\right)$ caused mineralogic transformations of 2-line Si-ferrihydrite through heterogeneous electron transfer that may be approximated as follows:

$2 \mathrm{Fe}(\mathrm{OH})_{3}+\mathrm{AH} 2 \mathrm{DS}+4 \mathrm{H}^{+}=2 \mathrm{Fe}^{2+}+\mathrm{AQDS}+6 \mathrm{H}_{2} \mathrm{O}$

The oxidation of $\mathrm{AH}_{2} \mathrm{DS}$ coupled to $\mathrm{Fe}(\mathrm{III})$ reduction leads to a significant increase in interfacial $\mathrm{pH}$, while subsequent reactions of $\mathrm{Fe}(\mathrm{II})$ including surface complexation, surface hydrolysis, and precipitation act to lower $\mathrm{pH}$.

The electron transfer reaction between $\mathrm{AH}_{2} \mathrm{DS}$ and 2line Si-ferrihydrite was rapid, generally reaching completion, e.g., full $\mathrm{AH}_{2} \mathrm{DS}$ oxidation, within 3-24 h (Figs. 1 and 7). Product $\mathrm{Fe}(\mathrm{II})$, redistributed over that time period to yield both aqueous and sorbed $\mathrm{Fe}(\mathrm{II})$, with aqueous $\mathrm{Fe}(\mathrm{II})$ decreasing somewhat with aging between 1 and $30 \mathrm{~d}$ for $\mathrm{Fe}(\mathrm{II})_{\text {equiv }} / \mathrm{Fe}(\mathrm{III})=0.54$ only (Fig. 7). There were no significant differences in $\mathrm{Fe}(\mathrm{II})_{\mathrm{aq}} / \mathrm{Fe}(\mathrm{II})_{\text {sorb }}$ distributions between the AQDS and $\mathrm{Fe}(\mathrm{II})_{\mathrm{aq}}$ systems at comparable concentrations. Neither $\mathrm{AH}_{2} \mathrm{DS}$ nor its oxidized form displays any measureable distribution to the solid phase (Liu et al., 2007a).

The primary mineral products of $\mathrm{AH}_{2} \mathrm{DS}$ reaction ( $30 \mathrm{~d}$ ) were lepidocrocite and goethite (when $\mathrm{C}$ was present) at low reductant concentrations $\left.\left[\mathrm{Fe}(\mathrm{II})_{\text {equiv }} / \mathrm{Fe}(\mathrm{III})=0.11\right]\right)$, and magnetite at higher concentration $\left[\mathrm{Fe}(\mathrm{II})_{\text {equiv }} / \mathrm{Fe}(\mathrm{III})=\right.$ 0.54]). This product suite was the same observed by Hansel et al. (2005) and Liu et al. (2007b) using Fe(II) aq as the reactant. The presence of bicarbonate encouraged goethite formation over lepidocrocite with $\mathrm{AH}_{2} \mathrm{DS}$ as the reactant, as observed by others for the Fe(II) system (Schwertmann and Thalmann, 1976; Cornell and Schwertmann, 2003; Hansel et al., 2005). XRD measurements after the initial $1 \mathrm{~d}$ of reaction displayed nascent patterns consistent with the final products when they consisted of goethite (Fig. 2D) and magnetite (Fig. 8). The $1 \mathrm{~d}$ XRD pattern of treatment \#1 ( $-\mathrm{P}-\mathrm{C}$ ) that yielded lepidocrocite (Fig. 2B), however, showed little difference from the control.

Interfacial electron transfer was proposed to be the initial step in the transformation of 2-line ferrihydrite to 
lepidocrocite or goethite via dissolution-reprecipitation in suspensions containing $\mathrm{Fe}(\mathrm{II})_{\mathrm{aq}}$ concentrations comparable to our $\mathrm{Fe}(\mathrm{II})_{\text {equiv }} / \mathrm{Fe}(\mathrm{III})=0.11 \mathrm{AH}_{2} \mathrm{DS}$ system (Hansel et al., 2005; Pedersen et al., 2005). The noted presence of various morphologies of lepidocrocite (tabs, elongated cubes or tubes, and rosettes) with both compact and porous crystal structures in our $\mathrm{AH}_{2} \mathrm{DS}$ experiments (Fig. 3), implied multiple formation pathways and additional complexity. Tabular lepidocrocite, formed by reductive dissolution and reprecipitation (Cornell et al., 1989a; Cornell and Schwertmann, 2003), is the most commonly reported morphologic form. The tabular morphology was observed in both $\mathrm{AH}_{2} \mathrm{DS}$ (Fig. 3B) and $\mathrm{Fe}(\mathrm{II})_{\mathrm{aq}}$ (Fig. 12) systems. The cube-like/tubular lepidocrocite morphology (Fig. 3AC) and porous crystal forms (Fig. 3F and G) were distinct to the $\mathrm{AH}_{2} \mathrm{DS}$ system, and implied a second mechanism of growth. The buried interface (Fig. $3 \mathrm{H}$ ) indicated growth of lepidocrocite from ferrihydrite by aggregation, as noted previously for a biotic system with co-associated goethite and ferrihydrite (Banfield et al., 2000). Selected area diffraction (SAED) and nanodiffraction (Fig. 3F and G) revealed that the crystallographic axes of all the particles in the aggregate were parallel, with the same three-dimensional orientation. The SAED patterns of this material matched well with lepidocrocite, while the aggregate behaved as a single crystal under nanodiffraction (Fig. $3 F$ and $G$ ). The compact crystals (Fig. 3D) also displayed lepidocrocite SAED patterns, but their formation pathways, e.g., dissolution-reprecipitation or porous crystal maturation were not discernable.

Small amounts of C in PIPES buffer $(>0.8 \%)$ facilitated the transformation of 2-line Si-ferrihydrite by $\mathrm{AH}_{2} \mathrm{DS}$ to goethite (Fig. 2D) instead of lepidocrocite. Others (Cornell et al., 1989b; Carlson and Schwertmann, 1990) have observed that ferrihydrite transformation to lepidocrocite and/or goethite by $\mathrm{Fe}(\mathrm{II})_{\mathrm{aq}}$ and L-cysteine is influenced by $\mathrm{C}$ concentration. L-Cysteine/cystine has a similar half-cell potential to AQDS (Jones et al., 2004), but is adsorbed more strongly by ferrihydrite. Bicarbonate is believed to suppress lepidocrocite nucleation (Cornell et al., 1989a). Acicular goethite crystals with proximate ferrihydrite were common in this study (Fig. 5D and E), indicating direct transformation from ferrihydrite with time (Hansel et al., 2005). A goethite precursor, such as 6-line ferrihydrite, was not evident by XRD (Fig. 2D). There was no evidence for aggregation-induced crystallization of goethite in presence of $\mathrm{C}$, and goethite was not observed as a precursor to magnetite formation as reported by Coker et al. (2008).

Five differences were observed in ferrihydrite transformation by $\mathrm{AH}_{2} \mathrm{DS}$ as compared to $\mathrm{Fe}(\mathrm{II})_{\mathrm{aq}}$ in the absence of P: (i) the formation rate of lepidocrocite was more rapid in presence of $\mathrm{Fe}(\mathrm{II})_{\mathrm{aq}}$ at all $\mathrm{Fe}(\mathrm{II})_{\text {equiv }} / \mathrm{Fe}(\mathrm{III})$ ratios, (ii) multiple morphologic forms of lepidocrocite were observed with $\mathrm{AH}_{2} \mathrm{DS}$ as the reactant, while $\mathrm{Fe}(\mathrm{II})_{\mathrm{aq}}$ produced only tabular forms, (iii) $\mathrm{AH}_{2} \mathrm{DS}$ was more effective then $\mathrm{Fe}(\mathrm{II})_{\mathrm{aq}}$ in promoting magnetite formation at higher $\mathrm{Fe}(\mathrm{II})_{\text {equiv }} /$ $\mathrm{Fe}$ (III) ratios, (iv) magnetite formation with $\mathrm{Fe}(\mathrm{II})_{\mathrm{aq}}$ appeared to occur in parallel with lepidocrocite formation, albeit at slower initial rate, and (v) magnetite formation with $\mathrm{AH}_{2} \mathrm{DS}$ appeared to occur by solid-state conversion of aggregated ferrihydrite without a competitive reaction or precursor. We note the possibility that differences between the $\mathrm{AH}_{2} \mathrm{DS}$ and $\mathrm{Fe}(\mathrm{II})_{\mathrm{aq}}$ systems at $\mathrm{Fe}(\mathrm{II})_{\text {equiv }} / \mathrm{Fe}(\mathrm{III}) \approx 0.5$ where magnetite formation occurred may have resulted from $\mathrm{pH}$ which was one unit higher in the $\mathrm{AH}_{2} \mathrm{DS}$ experiment (Table 2). Increasing $\mathrm{pH}$ above neutrality promotes magnetite formation (Mann et al., 1989; Faivre et al., 2004; Hansel et al., 2005).

Differences were also observed between our $\mathrm{Fe}(\mathrm{II})_{\mathrm{aq}}$ system results and those of Hansel et al. (2005), and their resulting conceptual model of $\mathrm{Fe}(\mathrm{II})_{\mathrm{aq}}$-induced mineralization. Before making these comparisons we note that different starting materials were used. Hansel et al. (2005) used ferrihydrite that was air-dried to form a coating on silica sand, while the experiments described herein utilized a moderately aggregated, Si-substituted, 2-line ferrihydrite suspension. Undoubtedly, differences exist in the fundamental recrystallization rates of these two ferrihydrite preparations as a result of synthesis procedure and history, chemical bonding to the surface of silica ( $\mathrm{Xu}$ and Axe, 2005), hydration, aggregation, and other physicochemical effects as noted by Kukkadapu et al. (2003). Bearing in mind these differences, there are several significant comparisons. First, Hansel et al. noted that the rates of lepidocrocite precipitation were nearly 10 times faster at higher $\mathrm{Fe}(\mathrm{II})_{\mathrm{aq}}$. Based on XRD peak height comparisons (Figs. 10, 11 and EA-6), we observed no apparent dependency of lepidocrocite formation on $\mathrm{Fe}(\mathrm{II})_{\mathrm{aq}}$ concentrations. Second, Hansel et al. noted that magnetite accumulates at the expense of lepidocrocite, implying that lepidocrocite was a precursor to magnetite formation. We observed that magnetite accumulates in parallel with lepidocrocite, albeit at an initially slower rate. Finally, Hansel et al. suggested that the dissolution of lepidocrocite can provide Fe(III) for continued magnetite growth after ferrihydrite has been exhausted. In contrast, we observed that lepidocrocite, once formed, was stable in our experiments for $63 \mathrm{~d}$ regardless of $\mathrm{Fe}(\mathrm{II})_{\mathrm{aq}}$ concentration.

The transformation pathway with $0.5 \times 10^{-3} \mathrm{~mol} \mathrm{~L}^{-1}$ $\mathrm{Fe}(\mathrm{II})_{\mathrm{aq}}$ and $1.0 \times 10^{-2} \mathrm{~mol} \mathrm{~L}^{-1}$ ferrihydrite was similar to that with $\mathrm{AH}_{2} \mathrm{DS}$ at $\mathrm{Fe}(\mathrm{II})_{\text {equiv }} / \mathrm{Fe}(\mathrm{III})=0.11$, except that the $\mathrm{Fe}(\mathrm{II})_{\mathrm{aq}}$ system evolved to lepidocrocite much more rapidly (Table 2). Lepidocrocite was also the primary shortterm product at higher $\mathrm{Fe}(\mathrm{II})_{\mathrm{aq}}$ concentrations $\left(3.3 \times 10^{-3}\right.$ and $\left.5.0 \times 10^{-3} \mathrm{~mol} \mathrm{~L}^{-1}\right)$ with significant co-existing ferrihydrite (Fig. 10). There was no evidence for green rust in any of our experiments, an often observed precursor of lepidocrocite during Fe(II) oxidation (Cornell and Schwertmann, 2003, and references therein). While Si is recognized to effect the formation of ferrihydrite and its transformation to $\mathrm{FeOOH}$ forms under oxidizing conditions (Schwertmann et al., 2004); the level of adsorbed silica in our system had no apparent effect on the rapid formation of lepidocrocite under reducing conditions. Lepidocrocite was the reaction product of ferrihydrite and $\mathrm{FeCl}_{2}$ at $<1 \times$ $10^{-3} \mathrm{~mol} \mathrm{~L}^{-1} \mathrm{Fe}(\mathrm{II})_{\mathrm{aq}}$ (Hansel et al., 2005; Pedersen et al., 2005; Borch et al., 2007), and the sole short term product at higher concentrations (e.g., $2.0 \times 10^{-3} \mathrm{~mol} \mathrm{~L}^{-1}$ $\mathrm{Fe}(\mathrm{II}) \mathrm{Cl}_{2}$; Hansel et al., 2005). These past studies suggest that ferrihydrites treated with $>1.0 \times 10^{-3} \mathrm{~mol} \mathrm{~L}^{-1} \mathrm{Fe}$ (II) 
recrystallize to magnetite via "metastable" lepidocrocite. This pathway, however, was not observed in our $3.3 \times 10^{-3}$ and $5 \times 10^{-3} \mathrm{~mol} \mathrm{~L}^{-1} \mathrm{Fe}(\mathrm{II})$ systems, where magnetite formed in parallel to, and not from lepidocrocite (Fig. 10). Beyond this, lepidocrocite showed little metastability as it persisted for $63 \mathrm{~d}$ in presence of high $\mathrm{Fe}(\mathrm{II})_{\mathrm{aq}}$ under conditions that were well within the aqueous stability field of magnetite as revealed by thermodynamic calculation.

\subsection{Influence of $P$}

In the $\mathrm{Fe}(\mathrm{II})_{\text {equiv }} / \mathrm{Fe}(\mathrm{III})=0.11 \mathrm{AH}_{2} \mathrm{DS}$ system, $\mathrm{P}(2 \%)$ "stabilized" the 2-line Si-ferrihydrite structure from transforming to lepidocrocite $(-\mathrm{C}$, PIPES) or goethite $(+\mathrm{C}$, PIPES). Similar results at comparable $\mathrm{P}$ concentrations have been previously reported (Galvez et al., 1999; Borch et al., 2007). Phosphate is strongly adsorbed by ferrihydrite, apparently forming a stable bidentate surface complex at circumneutral pH (Arai and Sparks, 2001; Khare et al., 2007). Strong P adsorption decreases the ferrihydrite transformation rate by preventing the relatively soluble structure from dissolution and subsequent reprecipitation (Biber et al., 1994; Galvez et al., 1999; Majzlan, 2008). Phosphate apparently overwhelms the influence of sorbed (adsorbed or coprecipitated) silica in our ferrihydrite preparation, possibly through competitive displacement, because of its stronger surface complexation (approximately 1000 times greater, Dzombak and Morel, 1990). Previous studies have shown that P displaces co-precipitated Si from ferrihydrite and that the Si concentration used here does not influence reductive ferrihydrite mineralization (Kukkadapu et al., 2004). Sorbed Si is however, important for ferrihydrite stabilization in oxic environments (Carlson and Schwertmann, 1981).

The absence of crystalline $\mathrm{Fe}(\mathrm{III})$-oxides in $+\mathrm{P}(2 \%)$ systems was curious given that $\mathrm{Fe}(\mathrm{II})_{\mathrm{aq}}$ concentrations and $\mathrm{Fe}(\mathrm{II})_{\mathrm{aq}} / \mathrm{Fe}(\mathrm{II})_{\text {sorb }}$ ratios were similar in both the $+\mathrm{P}$ and -P systems (Fig. 1). Moreover, the chemical environment of sorbed $\mathrm{Fe}(\mathrm{II})$ in samples with and without $\mathrm{P}$ was similar as measured by Mössbauer spectroscopy (see * positions in Fig. 6B and E). Mossbauer parameters for the Fe(II) doublet were comparable to sorbed $\mathrm{Fe}(\mathrm{II})$ on ferrihydrite as reported by Tronc et al. (1992), and $\mathrm{Fe}(\mathrm{II})$ sorbed on hematite above site saturation (Larese-Casanova and Scherer, 2007). This Fe(II) species, however, was different from that identified as: (i) a precursor of green rust in a AQDS- and P-containing MRB system (Kukkadapu et al., 2004), and (ii) the Fe(II)-Fe(III) solid-phase redox product of $\mathrm{Tc}(\mathrm{VII})-\mathrm{Fe}(\mathrm{II})$ homogeneous reaction (Zachara et al., 2007). The Fe(II)-ferrihydrite in these latter two systems, despite higher $\mathrm{Fe}(\mathrm{II})$ content, displayed only broad sextets at $77 \mathrm{~K}$ unlike the distinct $\mathrm{Fe}(\mathrm{II})$ doublet noted in the present samples at $\geqslant 77 \mathrm{~K}$ (Fig. 6B and C).

It was not possible from Mössbauer spectroscopy to determine whether sorbed $\mathrm{Fe}(\mathrm{II})$ resulting from $\mathrm{AH}_{2} \mathrm{DS}$ reaction in the presence of $\mathrm{P}$ was adsorbed to or precipitated with ferrihydrite, or present as a separate phase. Perhaps the distinction between surface complexes and structural incorporation is insignificant given the disor- dered ferrihydrite structure (Michel et al., 2007). We did not observe an octet pattern for sorbed Fe(II) at $10 \mathrm{~K}$. This Mössbauer feature was reported for surface-associated $\mathrm{Fe}(\mathrm{II})$ on hematite above site saturation, and was attributed to a $\mathrm{Fe}(\mathrm{OH})_{2}$-like phase (Larese-Casanova and Scherer, 2007). The observed Mössbauer parameters of Fe(III) and $\mathrm{Fe}(\mathrm{II})$ in the $+\mathrm{P}$ sample, and their temperature dependence, implied that the reacted mineral residue retained the starting ferrihydrite structure with sorbed Fe(II) in highly distorted environments. The minor differences in the ferrihydrite features resulted from the formation of 6-line from 2-line ferrihydrite (Figs. 4 and 6).

The reductive mineralization of ferrihydrite at $\mathrm{Fe}(\mathrm{II})_{\mathrm{e}}$ quiv $/ \mathrm{Fe}(\mathrm{III})=0.54$ in the $\mathrm{AH}_{2} \mathrm{DS}$ system, where sorbed $\mathrm{Fe}$ (II) was $\sim 33 \%$ of $\mathrm{Fe}_{\text {total }}$, was similar in both $+\mathrm{P}$ and -P systems. Stoichiometric magnetite was the only product (Fig. 8). There were no hints of green rust, lepidocrocite, or any other precursor in the 77-K Mössbauer spectrum (not shown). The presence of incipient peaks due to magnetite in the $1 \mathrm{~d}$ samples implied solid-state conversion induced by $\mathrm{Fe}(\mathrm{II})$ sorption and electron transfer to structural $\mathrm{Fe}$ (III) (Cornell, 1988; Mann and Frankel, 1989; Tronc et al., 1992). The morphology of the magnetite was different from those created by dissolution/precipitation (Vali et al., 2004; Behrends and Van Cappellen, 2007). Sorbed P had no apparent influence on this $\mathrm{AH}_{2} \mathrm{DS}$-mediated solid-state reaction that was different from the proposed $\mathrm{Fe}(\mathrm{II})$-rich ferrihydrite to lepidocrocite to magnetite pathway of the aqueous Fe(II)-ferrihydrite system (Hansel et al., 2005). Perhaps higher interfacial $\mathrm{pH}$ promoted by $\mathrm{AH}_{2} \mathrm{DS}$ oxidation facilitated $\mathrm{P}$ desorption.

The presence of $\mathrm{P}$ inhibited 2-line Si-ferrihydrite transformation to lepidocrocite in PIPES buffer over a $1 \mathrm{~d}$ reaction period at all studied concentrations of $\mathrm{Fe}(\mathrm{II})_{\mathrm{aq}}$ (Fig. 11 and EA-6). However, this inhibition was relieved over time as comparable amounts of lepidocrocite were observed in the $+\mathrm{P}$ and $-\mathrm{P}$ systems after $30 \mathrm{~d}$ (Figs. 10 and 11). These concentrations did not change after an additional $33 \mathrm{~d}$ of equilibration (to $63 \mathrm{~d}$, Fig. EA-5). The initial inhibition did not result from any change in $\mathrm{Fe}(\mathrm{II})$ solid-liquid distribution (i.e., electron transfer) as $\mathrm{Fe}(\mathrm{II})_{\mathrm{aq}}$ concentrations were insensitive to the presence of $\mathrm{P}$ (Fig. 9). In contrast to the $\mathrm{AH}_{2} \mathrm{DS}$ system, the presence of $\mathrm{P}$ strongly inhibited magnetite formation by $\mathrm{Fe}(\mathrm{II})_{\mathrm{aq}}$. A comparable observation was made by Borch et al. (2007). System pH may have been a factor in our experiments as a lower $\mathrm{pH}$ in the $\mathrm{Fe}(\mathrm{II})_{\mathrm{aq}}$ system may have both strengthened $\mathrm{P}$ surface complexation, and lowered the magnetite formation rate. This apparent inhibition did not diminish even after $63 \mathrm{~d}$ of incubation. Adsorbed $\mathrm{P}$ may hinder reductive mineralization by blocking condensation sites at the nm scale necessary for formation of long-range order.

An unresolved issue in the current study is the fate of $\mathrm{Si}$ that was coprecipitated with ferrihydrite. We have noted in previous studies that the coprecipitated $\mathrm{Si}$ is labile and responsive to $\mathrm{P}$ concentration. Si changes in solid-liquid distribution during ferrihydrite phase transformations (Kukkadapu et al., 2004). It is also not conservative once released to the aqueous phase and may substitute to limited degrees in reductive transformation products (Glasauer 
et al., 1999; Schwertmann et al., 2004), and adsorb to their surfaces (Eick et al., 2009). The trajectory of aqueous and ferrihydrite-sorbed $\mathrm{Si}$ during the course of the present experiments is not known. Is it possible for desorbed $\mathrm{Si}$ to further enrich $\mathrm{Si}$ in the residual ferrihydrite to levels that impact its subsequent reactivity with $\mathrm{Fe}(\mathrm{II})$ ? The behavior of $\mathrm{Si}$ should be considered in future experiments given the recent results of Jones et al. (2009).

\subsection{Implications to MRB-AQDS-ferrihydrite systems}

When AQDS is used as a ETM with MRB, an electron donor, and ferrihydrite/or lepidocrocite, it is generally present at lower concentration with a $\mathrm{Fe}(\mathrm{II})_{\text {equiv }} / \mathrm{Fe}(\mathrm{III})$ ratio ranging from approximately 0.0004 (Zegeye et al., 2007; Coker et al., 2008) to 0.0072 (Fredrickson et al., 1998; Kukkadapu et al., 2004). Consequently, the heterogeneous reductant $\left(\mathrm{AH}_{2} \mathrm{DS}\right)$ is supplied at a low, but more sustained and uniform concentration than in the present experiments as a result of bacterial respiration. The system is flux-, rather than concentration-driven. The total electron equivalents delivered to the solid are a complex function of the electron donor concentration, respiration rate (organism density), and AQDS concentration (Zegeye et al., 2007; O'Loughlin, 2008); and not the total concentration of AQDS as observed here.

Comparisons between +AQDS and -AQDS systems suggest that the primary role of AQDS is to enhance reduction/mineralization kinetics, reaction product crystallization, and the dispersal of electron equivalents to less accessible domains, e.g., within aggregates or mineral surfaces not in cell contact (Fredrickson et al., 1998; Zachara et al., 1998; Coker et al. 2008; Zegeye et al., 2007; Cutting et al., 2009). The presence of AQDS may also reduce the temporal stability of mineralogic intermediates (Coker et al., 2008). Consistent with the results of this study, the presence of AQDS enhanced magnetite formation by MRB from both ferrihydrite and lepidocrocite (Cutting et al., 2009). While these authors attributed their observations to enhanced Fe(II) flux mediated by AQDS, it is more probable that this was a direct AQDS effect as observed herein. Uncertain is the role of interfacial $\mathrm{pH}$ on reductive mineralization as influenced by heterogeneous $\mathrm{AH}_{2} \mathrm{DS}$ oxidation, either as a temporal excursion or sustained condition.

The long-term persistence of lepidocrocite in our $\mathrm{Fe}(\mathrm{II})_{\mathrm{aq}}$ system (e.g., $63 \mathrm{~d}$, Fig. 10), contrasted with its transformation by MRB under comparable or shorter time periods (Vali et al., 2004; Cutting et al., 2009; O'Loughlin et al., 2010). Consistent with our findings, both Pedersen et al. (2005) and Hansel et al. (2005) also noted little transformation of lepidocrocite to magnetite by $\mathrm{Fe}(\mathrm{II})_{\mathrm{aq}}$ in the absence of MRB activity. Magnetite, in contrast, was an important bioreduction product of lepidocrocite by: (i) Geobacter sulfurreducens in bicarbonate buffer after $6 \mathrm{~d}$ (Cutting et al., 2009), that was enhanced by AQDS presence, and (ii) Shewanella putrefaciens in presence of AQDS in unbuffered media after $50 \mathrm{~d}$ (O'Loughlin et al., 2010). Vali et al. (2004) observed the formation of lepidocrocite from ferrihydrite in $6.25 \mathrm{~d}$ using Geobacter metallireducens in PIPES buffer, and its subsequent complete transformation to tabular, single domain magnetite in $27.8 \mathrm{~d}$. Our results, however, showed that an elevated $\mathrm{Fe}(\mathrm{II})_{\mathrm{aq}}$ concentration and favorable $\mathrm{pH}$, as well as aqueous chemical conditions in the magnetite stability range, are alone insufficient to induce lepidocrocite transformation to magnetite over $63 \mathrm{~d}$. These noted differences may result from crystallite size/reactivity effects (our recrystallized lepidocrocite was relatively large in size, Fig. 12) or a potentially active, direct role of MRB in the lepidocrocite to magnetite transformation.

Green rust is a reductive mineralization product in MRB-AQDS-ferrihydrite (Fredrickson et al., 1998; Kukkadapu et al., 2004) and lepidocrocite systems (O'Loughlin et al., 2007, 2010; Zegeye et al., 2007; O'Loughlin, 2008). While green rust has been observed without AQDS (OnaNguema et al., 2002; Zegeye et al., 2007); the ETM has been a common component of media in which significant green rust has formed. Important differences exist between these studies in media composition including $\mathrm{P}$ and $\mathrm{C}$; cell concentrations influencing aggregation state and respiration rate [e.g., $\mathrm{Fe}(\mathrm{II})$ and bicarbonate flux]; $\mathrm{Fe}(\mathrm{III})$ oxide preparation method and crystallite size, storage history, and concentration; buffer use and concentration; and other experimental variables. Consequently, the identification of common mineral transformation pathways and the distinctive role of AQDS is difficult. Moreover, green rust is not always the final mineral product formed; and, for both ferrihydrite and lepidocrocite, specific conditions seem to be required, e.g., the presence of P (Bocher et al., 2004; Kukkadapu et al., 2004). For lepidocrocite specifically, high cell concentrations that promote as yet undefined aggregation effects appear necessary for green rust formation (Zegeye et al., 2007). Beyond this, it is perhaps significant that green rust is most frequently observed in un-buffered systems where $\mathrm{pH}$ increases to values over 8 in consequence to iron reduction.

Green rust formation did not occur in our experiments with $\mathrm{AH}_{2} \mathrm{DS}$ regardless of reactant ratio. Consequently, green rust appears to be a biogenic phase in certain settings controlled by unique combinations of experimental variables. Whether these conditions can be achieved in natural biogeochemical environments with significant natural $\mathrm{pH}$ buffering capacity, and in the absence of a low redox potential ETM such as AQDS is uncertain. Also uncertain is whether natural ETM, including humic substances (e.g., Nurmi and Tratnyek, 2002; Jiang and Kappler, 2008) and biogenic flavins (Marsili et al., 2008; Von Canstein et al., 2008; Ross et al., 2009) can function equally or even significantly in this regard.

\section{CONCLUSIONS}

Ferrihydrite is one of the most important Fe(III) oxides in subsurface environments because of its common occurrence and high reactivity. The findings presented herein complement other recent investigations on the reductive transformations of ferrihydrite. While there is general consensus on the nature of reductive transformation products and some of the conditions that promote them (e.g., this pa- 
per, Hansel et al., 2005; Borch et al., 2007; Coker et al., 2008), there is disagreement on pathways, the presence or absence of intermediate or precursor phases, kinetic relationships, and transformation mechanisms. To large degree, these disagreements result from: (i) the large number of important influential (bio)geochemical variables and their relevant ranges (e.g., $\mathrm{pH}, \mathrm{Fe}(\mathrm{II})$ concentration, ferrihydrite concentration and nature, carbonate concentration, presence or absence of $\mathrm{Si}$, presence or absence of ETM; etc.) and the inability to control or vary them in a suitably robust manner, and (ii) experimental differences and analytical methods. A truly integrative conceptual model of ferrihydrite reductive transformation in absence and presence of MRB will require precise control of key geochemical parameters over a large multi-dimensional domain, innovative experimentation, and application of multiple complementary analytical methods over critical timescales.

\section{ACKNOWLEDGMENTS}

This research was supported by the Geosciences Research Program of the Office of Basic Energy Science (BES), US Department of Energy (DOE). X-ray diffraction (XRD), electron microscopy, and Mössbauer measurements were performed using EMSL, a national scientific user facility sponsored by the Department of Energy's Office of Biological and Environmental Research and located at Pacific Northwest National Laboratory. PNNL is operated for the Department of Energy by Battelle. We acknowledge the assistance of Janae Strickland, Colleen Russell, and Odeta Qafoku with experimentation, XRD, and Mössbauer measurements. Appreciated comments and recommendations were provided by three anonymous reviewers that improved the manuscript.

\section{APPENDIX A. SUPPLEMENTARY DATA}

Supplementary data associated with this article can be found, in the online version, at doi:10.1016/j.gca.2011. 06.030 .

\section{REFERENCES}

Anderson P. R. and Benjamin M. M. (1985) Effect of silicon on the crystallization and adsorption properties of ferric oxides. Environ. Sci. Technol. 19, 1048-1053.

Arai Y. and Sparks D. L. (2001) ATR-FTIR spectroscopic investigation on phosphate adsorption mechanisms at the ferrihydrite-water interface. J. Colloid Interface Sci. 241, 317326.

Baedecker M. J., Cozzarelli I. M., Eganhouse R. P., Siegel D. I. and Bennett P. C. (1993) Crude oil in a shallow sand and gravel aquifer - III. Biogeochemical reactions and mass balance modeling in anoxic groundwater. Appl. Geochem. 8, 569-586.

Banfield J. F., Welch S. A., Zhang H., Ebert T. T. and Penn R. L. (2000) Aggregation-based crystal growth and microstructure development in natural iron oxyhydroxide biomineralization products. Science 289, 751-754.

Behrends T. and Van Cappellen P. (2007) Transformation of hematite into magnetite during dissimilatory iron reduction conditions and mechanisms. Geomicrobiol. J. 24, 403-416.
Bennett P. C., Siegel D. E., Baedecker M. J. and Hult M. F. (1993) Crude oil in a shallow sand and gravel aquifer - I. Hydrogeology and inorganic geochemistry. Appl. Geochem. 8, 529-549.

Bhushan B., Halasz A. and Hawari J. (2006) Effect of iron(III), humic acids, and anthraquinone-2,6-disulfonate on biodegradation of cyclic nitromines by Clostridium sp. EDB2. J. Appl. Microbiol. 100, 555-563.

Biber M. V., Dos Santos Afonso M. and Stumm W. (1994) The coordination chemistry of weathering: IV. Inhibition of the dissolution of oxide minerals. Geochim. Cosmochim. Acta 58, 1999-2010.

Bocher F., Gehin A., Ruby C., Ghanbaja J., Abdelmoula M. and Genin J.-M. R. (2004) Coprecipitation of Fe(II-III) hydroxycarbonate green rust stabilized by phosphate adsorption. Solid State Sci. 6, 117-124.

Bonneville S., Van Cappellen P. and Behrends T. (2004) Microbial reduction of iron(III) oxyhydroxides: effects of mineral solubility and availability. Chem. Geol. 212, 255-268.

Borch T., Inskeep W. P., Harwood J. A. and Gerlach R. (2005) Impact of ferrihydrite and anthraquinone-2,6-disulfonate on the reductive transformation of 2,4,6-trinitrotoluene by a grampositive fermenting bacterium. Environ. Sci. Technol. 39, 71267133.

Borch T., Masue Y., Kukkadapu R. K. and Fendorf S. (2007) Phosphate imposed limitations on biological reduction and alteration of ferrihydrite. Environ. Sci. Technol. 41, 166172.

Burgos W. D., Fang Y. L., Royer R. A., Yeh G. T., Stone J. J., Jeon B. H. and Dempsey B. A. (2003) Reaction-based modeling of quinone-mediated bacterial iron(III) reduction. Geochim. Cosmochim. Acta 67, 2735-2748.

Carlson L. and Schwertmann U. (1981) Natural ferrihydrites in surface deposits from Finland and their association with silica. Geochim. Cosmochim. Acta 45, 421-429.

Carlson L. and Schwertmann U. (1990) The effect of $\mathrm{CO}_{2}$ and oxidation rate on the formation of goethite versus lepidocrocite from a $\mathrm{Fe}(\mathrm{II})$ system at pH 6 and 7. Clay Miner. 25, 65-71.

Chacon N., Silver W. L., Dubinsky E. A. and Cusack D. F. (2006) Iron reduction and soil phosphorus solubilization in humid tropical forests soils: the roles of labile carbon pools and an electron shuttle compound. Biogeochemistry 78, 67-84.

Coker V. S., Bell A. M. T., Pearce C. I., Pattrick R. A. D., Van Der Laan G. and Lloyd J. R. (2008) Time-resolved synchrotron powder X-ray diffraction study of magnetite formation by the $\mathrm{Fe}(\mathrm{III})$-reducing bacterium Geobacter sulfurreducens. Am. Mineral. 93, 540-547.

Cornell R. M. (1988) The influence of some divalent cations on the transformation of ferrihydrite into more crystalline products. Clay Miner. 23, 329-332.

Cornell R. M. and Giovanoli R. (1987) The influence of silicate species on the morphology of goethite $(\alpha-\mathrm{FeOOH})$ grown from ferrihydrite $\left(5 \mathrm{Fe}_{2} \mathrm{O}_{3} \cdot 9 \mathrm{H}_{2} \mathrm{O}\right)$. JCS Chem. Commun., 413-414.

Cornell R. M., Giovanoli R. and Schindler P. W. (1987) Effect of silicate species on the transformation of ferrihydrite into goethite and hematite in alkaline media. Clays Clay Miner. 35, 21-28.

Cornell R. M., Giovanoli R. and Schneider W. (1989a) The transformation of ferrihydrite into lepidocrocite. Clay Miner. 24, 549-553.

Cornell R. M., Schneider W. and Giovanoli R. (1989b) Phase transformation in the ferrihydrite/cysteine system. Polyhedron 8, 2829-2834.

Cornell R. M. and Schwertmann U. (2003) The Iron Oxides: Structure, Reactions, Occurrences and Uses, 2nd ed. Wiley$\mathrm{VCH}$. 
Curtis G. P. and Reinhard M. (1994) Reductive dehalogenation of hexachlorethane, carbon-tetrachloride, and bromoform by anthrahydroquinone disulfonate and humic-acid. Environ. Sci. Technol. 28, 2392-2401.

Cutting R. S., Coker V. S., Fellowes J. W., Lloyd J. R. and Vaughan D. J. (2009) Mineralogical and morphological constraints on the reduction of $\mathrm{Fe}(\mathrm{III})$ minerals by Geobacter sulfurrenducens. Geochim. Cosmochim. Acta 73, 4004-4022.

DiChristina T. J., Fredrickson J. K. and Zachara J. M. (2005) Enzymology of electron transport: energy generation with geochemical consequences. In Reviews in Mineralogy \& Geochemistry, vol. 59 (eds. J. F. Banfield, J. Cervini-Silva and K. M. Nealson). Mineralogical Society of America, pp. 27-52.

Dong H. L., Kostka J. E. and Kim J. (2003) Microscopic evidence for microbial dissolution of smectite. Clays Clay Miner. 51, $502-512$.

Dyer L., Fawell P. D., Newman O. M. G. and Richmond W. R. (2010) Synethsis and characterization of ferrihydrite/silica coprecipitates. J. Colloid Interface Sci. 348, 65-70.

Dzombak D. A. and Morel F. M. M. (1990) Surface Complexation Modeling-Hydrous Ferric Oxide. John Wiley \& Sons, New York, NY.

Eick M. J., Luxton T. P. and Welsh H. A. (2009) Effect of silica polymerization on the oxalate-promoted dissolution of goethite. Clays Clay Miner. 57, 578-585.

Faivre D., Agrinier P., Menguy N., Zuddas P., Pachana K., Gloter A., Laval J-. Y. and Guyot F. (2004) Mineralogical and isotopic properties of inorganic nanocrystalline magnetites. Geochim. Cosmochim. Acta 68, 4395-4403.

Fortin D., Leppard G. G. and Tessier A. (1993) Characteristics of lacustrine diagenetic iron oxyhydroxides. Geochim. Cosmochim. Acta 57, 4391-4404.

Fredrickson J. K., Zachara J. M., Kennedy D. W., Dong H., Onstott T. C., Hinman N. W. and Li S. W. (1998) Biogenic iron mineralization accompanying the dissimilatory reduction of hydrous ferric oxide by a ground water bacterium. Geochim. Cosmochim. Acta 62, 3239-3257.

Fredrickson J. K., Zachara J. M., Kennedy D. W., Kukkadapu R. K., McKinley J. P., Heald S. M., Liu C., Plymale A. E. and Smith S. C. (2004) Reduction of $\mathrm{TcO}_{4}{ }^{-}$by sediment-associated biogenic Fe(II). Geochim. Cosmochim. Acta 68, 3171-3187.

Galvez N., Barron V. and Torrent J. (1999) Effect of phosphate on the crystallization of hematite, goethite, and lepidocrocite from ferrihydrite. Clays Clay Miner. 47, 304-311.

Geomicrobiology, (2002) Microbial Fe(III) oxide reduction. In $A n$ International Journal of Geomicrobiology and Microbial Biogeochemistry (eds. E. E. Roden and Y. A. Gorby), vol. 19. Taylor \& Francis, London, UK.

Glasauer S., Friedl J. and Schwertmann U. (1999) Properties of goethites prepared under acidic and basic conditions in the presence of silicate. J. Colloid Interface Sci. 216, 106-115.

Greenwood N. N. and Gibb T. C. (1971) Mössbauer Spectroscopy. Chapman and Hall, London.

Hansel C. M., Benner S. G., Neiss J., Dohnalkova A., Kukkadapu R. K. and Fendorf S. (2003) Secondary mineralization pathways induced by dissimilatory iron reduction of ferrihydrite under advective flow. Geochim. Cosmochim. Acta 67, 29772992.

Hansel C. M., Benner S. G. and Fendorf S. (2005) Competing $\mathrm{Fe}(\mathrm{II})$-induced mineralization pathways of ferrihydrite. Environ. Sci. Technol. 39, 7147-7153.

Hernandez M. E., Kappler A. and Newman D. K. (2004) Phenazines and other redox-active antibiotics promote microbial mineral reduction. Appl. Environ. Microbiol. 70, 921-928.
Jaisi D. P., Dong H. and Liu C. (2007) Influence of biogenic Fe(II) on the extent of microbial reduction of $\mathrm{Fe}(\mathrm{III})$ in clay minerals nontronite, illite, and chlorite. Geochim. Cosmochim. Acta 71, $1145-1158$.

Jiang J. and Kappler A. (2008) Kinetics of microbial and chemical reduction of humic substances: implications for electron shuttling. Environ. Sci. Technol. 42, 3563-3569.

Jones A. M., Collins R. N., Rose J. and Waite T. D. (2009) The effect of silica and natural organic matter on the $\mathrm{Fe}(\mathrm{II})$ catalyzed transformation and reactivity of $\mathrm{Fe}(\mathrm{III})$ minerals. Geochim. Cosmochim. Acta 72, 4409-4422.

Jones D. P., Y-Mi Go., Anderson C. L., Ziegler T. R., Kinkade J. M. and Kirlin W. (2004) Cysteine/cystine couple is a newly recognized node in the circuitry for biologic redox signaling and control. FASEB J. 18, 1246-1248.

Jones D. P., Fennessey C. M., DiChristina T. J. and Taillefert M. (2010) Shewanella oneidensis MR-1 mutants selected for their inability to produce soluble organic-Fe(III) complexes are unable to respire $\mathrm{Fe}(\mathrm{III})$ as anaerobic electron acceptor. Environ. Microbiol. 12, 938-950.

Kappler A. and Straub K. L. (2005) Geomicrobiological cycling of iron. Mol. Geomicrobiol. 59, 85-108.

Khare N., Martin J. D. and Hesterberg D. (2007) Phosphate bonding configuration of ferrihydrite based on molecular orbital calculations and XANES fingerprinting. Geochim. Cosmochim. Acta 71, 4404-4415.

Komlos J., Kukkadapu R. K., Zachara J. M. and Jaffe P. R. (2007) Biostimulation of iron reduction and subsequent oxidation of sediment containing Fe-silicates and Fe-oxides: effect of redox cycling on $\mathrm{Fe}(\mathrm{III})$ bioreduction. Water Res. 41, 2996-3004.

Kostka J. E., Dalton D. D., Skelton H., Dollhopf S. and Stucki J. W. (2002) Growth of iron(III)-reducing bacteria on clay minerals as the sole electron acceptor and comparison of growth yields on a variety of oxidized iron forms. Appl. Environ. Microbiol. 68, 6256-6262.

Kukkadapu R. K., Zachara J. M., Fredrickson J. K., Smith S. C., Dohnalkova A. C. and Russell G. K. (2003) Transformation of 2-line ferrihydrite to 6-line ferrihydrite under oxic and anoxic conditions. Am. Mineral. 88, 1903-1914.

Kukkadapu R. K., Zachara J. M., Fredrickson J. K. and Kennedy D. W. (2004) Biotransformation of synthetic 2-line silicaferrihydrite coprecipitates by a dissimilatory $\mathrm{Fe}(\mathrm{III})$-reducing bacterium: formation of carbonate green rust in the presence of phosphate. Geochim. Cosmochim. Acta 68, 2799-2814.

Kukkadapu R. K., Zachara J. M., Fredrickson J. K., Kennedy D. W., Dohnalkova A. C. and McCready D. E. (2005) Ferrous hydroxy carbonate is a stable transformation product of biogenic magnetite. Am. Mineral. 90, 510-515.

Kukkadapu R. K., Zachara J. M., Fredrickson J. K., McKinley J. P., Kennedy D. W., Smith S. C. and Dong H. (2006) Reductive biotransformation of $\mathrm{Fe}$ in shale-limestone saprolite containing $\mathrm{Fe}(\mathrm{III})$ oxides and $\mathrm{Fe}(\mathrm{II}) / \mathrm{Fe}(\mathrm{III})$ phyllosilicates. Geochim. Cosmochim. Acta 70, 3662-3676.

Kwon M. J. and Finneran K. T. (2006) Microbially mediated biodegradation of hexahydro-1,3,5-trinitro-1,3,5-triazine by extracellular electron shuttling compounds. Appl. Environ. Microbiol. 72, 5933-5941.

Kwon M. J. and Finneran K. T. (2008) Biotransformation products and mineralization potential for hexahydro-1,3,5trinitro-1,3,5-triazine (RDX) in abiotic versus biological degradation pathways with anthraquinone-2,6-disulfonate (AQDS) and Geobacter metallireducens. Biodegradation 19, 705-715.

Larese-Casanova P. and Scherer M. M. (2007) Fe(II) sorption on hematite: new insights based on spectroscopic measurements. Environ. Sci. Technol. 41, 471-477. 
Liu C., Zachara J. M., Foster N. S. and Strickland J. (2007a) Kinetics of reductive dissolution of hematite by bioreduced anthraquinone-2,6-difulfonate. Environ. Sci. Technol. 41, 77307735 .

Liu H., Li P., Zhu M. Y., Wei Y. and Sun Y. H. (2007b) Fe(II)induced transformation from ferrihydrite to lepidocrocite and goethite. J. Solid State Chem. 180, 2121-2128.

Lovley D. R. and Anderson R. T. (2000) Influence of dissimilatory metal reduction on the fate of organic and metal contaminants in the subsurface. Hydrogeol. J. 8, 77-88.

Majzlan J. (2008) Stabilization of iron oxide nanoparticles by the adsorption of sulfate, phosphate and arsenate. Geochim. Cosmochim. Acta 72(12), A587.

Mann S. and Frankel R. B. (1989) Magnetite biomineralization in unicellular microorganisms. In Biomineralization: Chemical and Biochemical Perspectives (eds. S. Mann, J. Webb and R. J. P. Williams). VCH, Weinheim, pp. 389-426.

Mann S., Sparks N. H. C., Couling S. B., Larcombe M. C. and Frankel R. B. (1989) Crystallochemical characterization of magnetic spinels prepared from aqueous solution. J. Chem. Soc. Faraday Trans. I 85, 3033-3044.

Marsili E., Baron D. B., Shikhare I. D., Coursolle D., Gralnick J. A. and Bond D. R. (2008) Shewanella secretes flavins that mediate extracellular electron transfer. PNAS 105, 3968-3973.

Mehta T., Coppi M. V., Childers S. E. and Lovley D. R. (2005) Outer membrane c-type cytochromes required for Fe(III) and $\mathrm{Mn}(\mathrm{IV})$ oxide reduction in Geobacter sulfurreducens. Appl. Environ. Microbiol. 71, 8634-8641.

Michel F. M., Ehm L., Antao S. M., Lee P. L., Chupas P. J., Liu G., Strongin D. R., Schoonen M. A. A., Phillips B. L. and Parise J. B. (2007) The structure of ferrihydrite, a nanocrystalline material. Science 316, 1726-1729.

Murad E. and Cashion J. (2004) Mössbauer Spectroscopy of Environmental Materials and Their Industrial Utilization. Kluwer Academic Publishers, Boston/Dordrecht/ New York/ London.

Nevin K. P. and Lovley D. R. (2000a) Lack of production of electron-shuttling compounds or solubilization of $\mathrm{Fe}(\mathrm{III})$ during reduction of insoluble $\mathrm{Fe}(\mathrm{III})$ oxide by Geobacter metallireducens. Appl. Environ. Microbiol. 66, 2248-2251.

Nevin K. P. and Lovley D. R. (2000b) Potential for nonenzymatic reduction of $\mathrm{Fe}(\mathrm{III})$ via electron shuttling in subsurface sediments. Environ. Sci. Technol. 34, 2472-2478.

Nurmi J. T. and Tratnyek P. G. (2002) Electrochemical properties of natural organic matter (NOM), fractions of NOM, and model biogeochemical electron shuttles. Environ. Sci. Technol. 36, 617-624.

O’Loughlin E. J., Larese-Casanova P., Scherer M. and Cook R. (2007) Green rust formation from the bioreduction of $\gamma$ $\mathrm{FeOOH}$ (lepidocrocite): comparison of several Shewanella species. Geomicrobiol. J. 24, 211-230.

O’Loughlin E. J. (2008) Effects of electron transfer mediators on the bioreduction of lepidocrocite $(\gamma-\mathrm{FeOOH})$ by Shewanella putrefaciens CN32. Environ. Sci. Technol. 42, 6876-6882.

O'Loughlin E. J., Gorski C. A., Scherer M. M., Boyanov M. I. and Kemner K. M. (2010) Effects of oxyanions, natural organic matter, and bacterial cell numbers on the bioreduction of lepidocrocite $(\gamma-\mathrm{FeOOH})$ and the formation of secondary mineralization products. Environ. Sci. Technol. 44, 45704576.

Ona-Nguema G., Abdelmoula M., Jorand F., Benali O., Géhin A., Block J.-C. and Génin J. M. R. (2002) Iron (II, III) hydroxycarbonate green rust formation and stabilization from lepidocrocite bioreduction. Geochim. Cosmochim. Acta 36, 16-20.
Pedersen H. D., Postma D., Jakobsen R. and Larsen O. (2005) Fast transformation of iron oxyhydroxides by the catalytic action of aqueous Fe(II). Geochim. Cosmochim. Acta 69, 3967-3977.

Perret D., Gaillard J. F., Dominik J. and Atteia O. (2000) The diversity of hydrous iron oxides. Environ. Sci. Technol. 34, 3540-3546.

Plymale A. E., Fredrickson J. K., Zachara J. M., Dohnalkova A. C., Heald S. M., Moore D. A., Kennedy D. W., Marshall M. J., Wang C. and Nachimuthu P. (2011) Competitive reduction of pertechnetate $\left({ }^{99} \mathrm{TcO}_{4}{ }^{-}\right)$by dissimilatory metal reducing bacteria and biogenic Fe(II). Environ. Sci. Technol. 45, 951-957.

Rancourt D. G. and Ping J. Y. (1991) Voigt-based methods for arbitrary-shape static hyperfine parameter distributions in Mössbauer spectroscopy. Nucl. Instrum. Methods Phys. Rev. B58, 85-87.

Roden E. E. and Zachara J. M. (1996) Microbial reduction of crystalline $\mathrm{Fe}(\mathrm{III})$ oxides: influence of oxide surface area and potential for cell growth. Environ. Sci. Technol. 30, 1618-1628.

Roden E. E. (2006) Geochemical and microbiological controls on dissimilatory iron reduction. C. R. Geosci. 338, 456-467.

Ross D. E., Brantley S. L. and Tien M. (2009) Kinetic characterization of OmcA and MtrC, terminal reductases involved in respiratory electron transfer for dissimilatory iron reduction in Shewanella oneidensis MR-1. Appl. Environ. Microbiol. 75, 5218-5226.

Royer R. A., Burgos W. D., Fisher A. S., Jeon B. H., Unz R. F. and Dempsey B. A. (2002) Enhancement of hematite bioreduction by natural organic matter. Environ. Sci. Technol. 36, 2897 2904.

Schwertmann U. and Thalmann H. (1976) The influence of [Fe(II)], [Si], and $\mathrm{pH}$ on the formation of lepidocrocite and ferrihydrite during oxidations of aqueous $\mathrm{FeCl}_{2}$ solutions. Clay Miner. 11, 189-200.

Schwertmann U. and Cornell R. M. (2000) Iron Oxides in the Laboratory. Wiley-VCH, Weiheim, Germany.

Schwertmann U., Friedel J. and Kyek A. (2004) Formation and properties of a continuous crystallinity series of synthetic ferrihydrites (2- to 6-line) and their relation to $\mathrm{FeOOH}$ forms. Clays Clay Miner. 52, 221-226.

Shi L., Squier T. C., Zachara J. M. and Fredrickson J. K. (2007) Respiration of metal (hydr)oxides by Shewanella and Geobacter: a key role for multihaem c-type cytochromes. Mol. Microbiol. 65, 12-20.

Shyu J. B. H., Lies D. P. and Newman D. K. (2002) Protective role of tolC in efflux of the electron shuttle anthraquinone-2,6disulfonate. J. Bacteriol. 184, 1806-1810.

Straub K. L. and Schink B. (2003) Evaluation of electron-shuttling compounds in microbial ferric iron reduction. FEMS Microbiol. Lett. 220, 229-233.

Stookey L. L. (1970) Ferrozine - A new spectrophotometric reagent for iron. Anal. Chem. 42, 779-781.

Swedlund P. J., Miskelly G. M. and McQuillan A. J. (2009) An attenuated total reflectance IR study of silicic acid adsorbed onto a ferric oxyhydroxide surface. Geochim. Cosmochim. Acta 73, 4199-4214.

Taillefert M., Beckler J. S., Carey E., Burns J. L., Fennessey C. M. and DiChristina T. J. (2007) Shewanella putrefaciens produces an $\mathrm{Fe}(\mathrm{III})$-solubilizing organic ligand during anaerobic respiration on insoluble Fe(III) oxides. J. Inorg. Biochem. 101, 17601767.

Tessier A., Fortin D., Belzile N., DeVitre R. R. and Leppard G. (1996) Metal sorption to diagenetic iron and manganese oxyhydroxides and associated organic matter: aarrowing the gap between field and laboratory measurements. Geochim. Cosmochim. Acta 60, 387-404. 
Tronc E., Belleville P., Jolivet J.-P. and Livage J. (1992) Transformation of ferric hydroxide into spinel by $\mathrm{Fe}(\mathrm{II})$ adsorption. Langmuir 8, 313-319.

Vali H., Weiss B., Li Y. L., Sears S. K., Kim S. S., Kirschvink J. L. and Zhang C. L. (2004) Formation of tabular single-domain magnetite induced by Geobacter metallireducens GS-15. PNAS 101, 16121-16126.

von Canstein H., Ogawa J., Shimizu S. and Lloyd J. R. (2008) Secretion of flavins by Shewanella species and their role in extracellular electron transfer. Appl. Environ. Microbiol. 74, 615-623.

Voordeckers J. W., Kim B. C., Izallalen M. and Lovley D. R. (2010) Role of Geobacter sulfurreducens outer surface c-type cytochromes in reduction of soil humic acid and anthraquinone-2,6-disulfonate. Appl. Environ. Microbiol. 76, 2371-2375.

Weber K. A., Achenbach L. A. and Coates J. D. (2006) Microorganisms pumping iron: anaerobic microbial iron oxidation and reduction. Nat. Rev. Microbiol. 4, 752-764.

$\mathrm{Xu}$ Y. and Axe L. (2005) Synthesis and characterization of iron oxide-coated silica and its effect on metal adsorption. J. Colloid Interface Sci. 282, 11-19.

Yan B., Wrenn B. A., Basak S., Biswas P. and Giammar D. E. (2008) Microbial reduction of $\mathrm{Fe}(\mathrm{III})$ in hematite nanoparticles by Geobacter sulfurreducens. Environ. Sci. Technol. 42, 65266531.

Zachara J. M., Fredrickson J. K., Li S. W., Kennedy D. W., Smith S. C. and Gassman P. L. (1998) Bacterial reduction of crystalline $\mathrm{Fe}(\mathrm{III})$ oxides in single phase suspensions and subsurface materials. Am. Mineral. 83, 1426-1443.
Zachara J. M., Kukkadapu R. K., Fredrickson J. K., Gorby Y. A. and Smith S. C. (2002) Biomineralization of poorly crystalline $\mathrm{Fe}(\mathrm{III})$ oxides by dissimilatory metal reducing bacteria (DMRB). Geomicrobiol. J. 19, 179-207.

Zachara J. M., Kukkadapu R. K., Gassman P. L., Dohnalkova A., Fredrickson J. K. and Anderson T. (2004) Biogeochemical transformation of $\mathrm{Fe}$ minerals in a petroleum-contaminated aquifer. Geochim. Cosmochim. Acta 68, 1791-1805.

Zachara J. M., Heald S. M., Jeon B.-H., Kukkadapu R. K., Liu C., McKinley J. P., Dohnalkova A. C. and Moore D. (2007) Reduction of pertechnetate $[\mathrm{Tc}(\mathrm{VII})]$ by aqueous $\mathrm{Fe}(\mathrm{II})$ and the nature of solid phase redox products. Geochim. Cosmochim. Acta 71, 2137-2157.

Zegeye A., Ruby C. and Jorand F. (2007) Kinetic and thermodynamic analysis during dissimilatory $\gamma-\mathrm{FeOOH}$ reduction: formation of green rust 1 and magnetite. Geomicrobiol. J. 24, 5164.

Zhang Y. Q., Zahir Z. A., Amrhein C., Chang A. and Frankenberger W. T. (2007) Application of redox mediator to accelerate selenate reduction to elemental selenium by Enterobacter taylorae. J. Agric. Food Chem. 55, 5714-5717.

Zhao J., Huggins F. E., Feng Z. and Huffman G. P. (1996) Surfaceinduced superparamagnetic relaxation in nanoscale ferrihydrite particles. Phys. Rev. B 54, 3403-3407.

Associate editor: Donald L. Sparks 